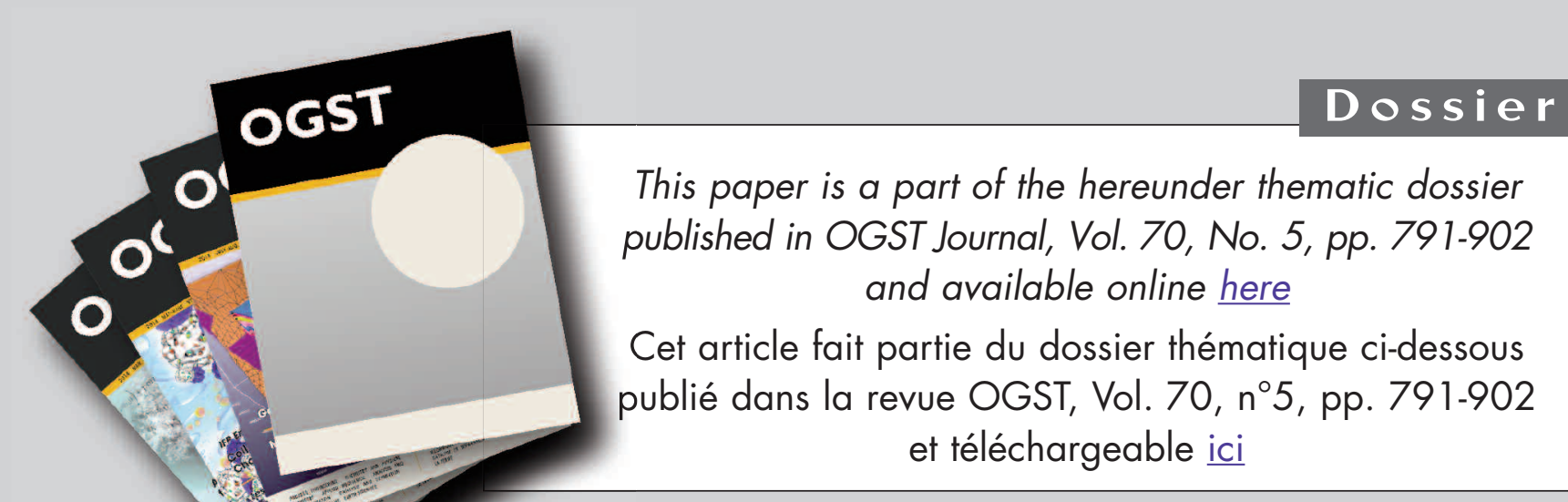

DOSSIER Edited by/Sous la direction de : D. Uzio

IFP Energies nouvelles International Conference / Les Rencontres Scientifiques d'IFP Energies nouvelles

$$
\begin{gathered}
\text { PHOTO4E - Photocatalysis for energy } \\
\text { PHOTO4E - Photocatalyse pour l'énergie }
\end{gathered}
$$

Oil \& Gas Science and Technology - Rev. IFP Energies nouvelles, Vol. 70 (2015), No. 5, pp. 791-902

Copyright (C) 2015, IFP Energies nouvelles

$791>$ Editorial

M. Fontecave, A. Fécant and D. Uzio

$799>$ Solar Production of Fuels from Water and $\mathrm{CO}_{2}$ : Perspectives and Opportunities for a Sustainable Use of Renewable Energy

Production solaire de carburants à partir de l'eau et de $\mathrm{CO}_{2}$ : perspectives et opportunités pour une utilisation durable de l'énergie renouvelable

R. Passalacqua, G. Centi and S. Perathoner

817 > Effect of Post-Synthesis Treatments on the Properties of ZnS Nanoparticles: An Experimental and Computational Study

Effet des traitements après-synthèse sur les propriétés de nanoparticules de ZnS : une étude expérimentale et computationnelle

E. Balantseva, B. Camino, A.M. Ferrari and G. Berlier

831 > Comparative Study on The Photocatalytic Hydrogen Production from Methanol over $\mathrm{Cu}_{-}, \mathrm{Pd}$-, Co- and Au-Loaded TiO

Étude comparative de production d'hydrogène par photocatalyse à partir de méthanol et à l'aide de différentes phases actives ( $\mathrm{Cu}, \mathrm{Pd}, \mathrm{Co}$ et Au) supportées sur TiO

P.P.C. Udani and M. Rønning

841 > Photocatalytic Conversion of Carbon Dioxide Using Zn-Cu-Ga Layered Double Hydroxides Assembled with Cu Phthalocyanine: Cu in Contact with Gaseous Reactant is Needed for Methanol Generation

Conversion photocatalytique du dioxyde de carbone par des hydroxydes doubles lamellaires de Zn-Cu-Ga promus par la phtalocyanine de Cu : nécessité du contact entre le Cu et le réactif gazeux pour la synthèse du méthanol

S. Kawamura, N. Ahmed, G. Carja and Y. Izumi
$853>$ Recyclable PhotoFuel Cell for Use of Acidic Water as a Medium Cellule photocombustible recyclable pour I'utilisation d'eau acide en tant que milieu

Y. Ogura, M. Yoshiba, and Y. Izumi

$863>$ Solar Hydrogen Reaching Maturity L'hydrogène solaire arrive à maturité

J. Rongé, T. Bosserez, L. Huguenin, M. Dumortier, S. Haussener and J.A. Martens

877 > Design of Compact Photoelectrochemical Cells for Water Splititing Conception de cellules photoélectrochimiques compactes pour la décomposition de l'eau

T. Bosserez, J. Rongé, J. van Humbeeck, S. Haussener and J. Martens

891 > Simultaneous Production of $\mathrm{CH}_{4}$ and $\mathrm{H}_{2}$ from Photocatalytic Reforming of Glucose Aqueous Solution on Sulfated Pd-TiO, Catalysts Production simultanée de $\mathrm{CH}_{4}$ et $\mathrm{H}_{2}$ par réformage photocatalytique d'une solution aqueuse de glucose sur un catalyseur Pd-TiO, sulfaté V. Vaiano, G. lervolino, G. Sarno, D. Sannino, L. Rizzo, J.J. Murcia Mesa, M.C. Hidalgo and J.A. Navío 


\title{
Photocatalytic Conversion of Carbon Dioxide Using Zn-Cu-Ga Layered Double Hydroxides Assembled with Cu Phthalocyanine: Cu in Contact with Gaseous Reactant is Needed for Methanol Generation
}

\author{
Shogo Kawamura', Naveed Ahmed', Gabriela Carja ${ }^{2}$ and Yasuo Izumi ${ }^{1 *}$ \\ ${ }^{1}$ Department of Chemistry, Graduate School of Science, Chiba University, Yayoi 1-33, Inage-ku, Chiba $263-8522$ - Japan \\ 2 Department of Chemical Engineering, Faculty of Chemical Engineering and Environmental Protection, Technical University "Gh. Asachi" of lasi, \\ Bd. Mangeron No. 71, lasi 700554 - Romania \\ e-mail: xOs3033@students.chiba-u.jp - nedoanjum@yahoo.com - carja@uaic.ro - yizumi@faculty.chiba-u.jp \\ * Corresponding author
}

\begin{abstract}
Photocatalytic conversion of $\mathrm{CO}_{2}$ into fuels is an attractive option in terms of both reducing the increased concentration of atmospheric $\mathrm{CO}_{2}$ as well as generating renewable hydrocarbon fuels. It is necessary to investigate good catalysts for $\mathrm{CO}_{2}$ conversion and to clarify the mechanism irradiated by natural light. Layered Double Hydroxides (LDH) have been attracting attention for $\mathrm{CO}_{2}$ photoreduction with the expectation of sorption capacity for $\mathrm{CO}_{2}$ in the layered space and tunable semiconductor properties as a result of the choice of metal cations. This study first clarifies the effects of $\mathrm{Cu}$ doping to $\mathrm{LDH}$ comprising $\mathrm{Zn}$ and $\mathrm{Al}$ or Ga. Cu could be incorporated in the cationic layers of $\mathrm{LDH}$ as divalent metal cations and/or interlayer anions as $\mathrm{Cu}(\mathrm{OH})_{4}{ }^{2-}$. The formation rates of methanol and $\mathrm{CO}$ were optimized for $\left[\mathrm{Zn}_{1.5} \mathrm{Cu}_{1.5} \mathrm{Ga}(\mathrm{OH})_{8}\right]^{+}{ }_{2} \mathrm{Cu}(\mathrm{OH})_{4}{ }^{2-} \cdot \mathrm{mH}_{2} \mathrm{O}$ at a total rate of $560 \mathrm{nmol} \mathrm{h}^{-1} \mathrm{~g}_{\mathrm{cat}}{ }^{-1}$ irradiated by UV-visible light. Cu phthalocyanine tetrasulfonate hydrate (CuPcTs ${ }^{4-}$ ) and silver were effective as promoters of $\mathrm{LDH}$ for $\mathrm{CO}_{2}$ photoreduction. Especially, the total formation rate using $\mathrm{CuPcTs}-\left[\mathrm{Zn} n_{3} \mathrm{Ga}(\mathrm{OH})_{8}\right]_{2}^{+}{ }_{2} \mathrm{CO}_{3}{ }^{2-} \cdot \mathrm{mH}_{2} \mathrm{O}$ irradiated by visible light was $73 \%$ of that irradiated by UV-visible light. The promotion was based on HOMOLUMO excitation of $\mathrm{CuPcTs}^{4-}$ by visible light. The LUMO was distributed on $\mathrm{N}$ atoms of pyrrole rings bound to central $\mathrm{Cu}^{2+}$ ions. The photogenerated electrons diffused to the $\mathrm{Cu}$ site would photoreduce $\mathrm{CO}_{2}$ progressively in a similar way to inlayer and interlayer $\mathrm{Cu}$ sites in the $\mathrm{LDH}$ in this study.
\end{abstract}

Résumé - Conversion photocatalytique du dioxyde de carbone par des hydroxydes doubles lamellaires de $\mathrm{Zn}-\mathrm{Cu}-\mathrm{Ga}$ promus par la phtalocyanine de $\mathrm{Cu}$ : nécessité du contact entre le $\mathrm{Cu}$ et le réactif gazeux pour la synthèse du méthanol - La conversion photocatalytique de $\mathrm{CO}_{2}$ est une option attractive pour limiter la concentration $\mathrm{du} \mathrm{CO}_{2}$ atmosphérique quand elle a pour objectif la production de produits hydrocarbonés utilisés comme carburants renouvelables. Néanmoins, des études sont encore nécessaires pour étudier les catalyseurs de conversion de $\mathrm{CO}_{2}$ et clarifier les mécanismes réactionnels. Des Hydroxydes Doubles Lamellaires (HDL) sont des catalyseurs intéressants pour la photoréduction de $\mathrm{CO}_{2}$ et l'on s'attend à obtenir une capacité d'adsorption du 
$\mathrm{CO}_{2}$ dans l'espace interlamellaire et des propriétés semi-conductrices adaptables par le choix des cations métalliques. La présente étude démontre tout d'abord les effets du dopage du $\mathrm{Cu}$ dans les HDL comprenant du $\mathrm{Zn}$ et de l'Al ou du Ga. Le cuivre pourrait être incorporé dans les couches cationiques des HDL sous forme de cations métalliques divalents et/ou d'anions inter-feuillets sous forme de $\mathrm{Cu}(\mathrm{OH})_{4}{ }^{2-}$. Les taux de formation du méthanol et du $\mathrm{CO}$ ont été optimum pour le $\left[\mathrm{Zn}_{1.5} \mathrm{Cu}_{1.5} \mathrm{Ga}(\mathrm{OH})_{8}\right]_{2}^{+} \mathrm{Cu}(\mathrm{OH})_{4}{ }^{2-} \cdot m \mathrm{H}_{2} \mathrm{O}$ correspondant à une vitesse totale de $560 \mathrm{nmol} \mathrm{h}^{-1} \mathrm{~g}_{\text {cat }}{ }^{-1}$, sous irradiation UV visible. Le tétrasulfonate-hydrate de phtalocyanine de $\mathrm{Cu}\left(\mathrm{CuPcTs}^{4-}\right)$ et l'argent se sont avérés être des promoteurs efficaces de HDL pour la photoréduction du $\mathrm{CO}_{2}$. En particulier, le taux de formation total en utilisant du CuPcTs- $\left[\mathrm{Zn}_{3} \mathrm{Ga}(\mathrm{OH})_{8}\right]^{+}{ }_{2} \mathrm{CO}_{3}{ }^{2-} \cdot m \mathrm{H}_{2} \mathrm{O}$ irradié par la lumière visible représentait $73 \%$ de celui irradié par de la lumière UV visible. La promotion a été attribuée à une excitation HOMO-LUMO du CuPcTs ${ }^{4-}$ par la lumière visible. Le LUMO répartie sur l'atome d'azote des cycles des pyrroles lié à l'ion central $\mathrm{Cu}^{2+}$. Les électrons photogénérés diffusés sur le site de $\mathrm{Cu}$ photoréduiraient le $\mathrm{CO}_{2}$ sur les sites cationiques (dans les couches) ou anioniques (interfeuillets) des HDL.

\section{INTRODUCTION}

Photocatalytic conversion of $\mathrm{CO}_{2}$ into fuels has emerged as an attractive option, in terms of both reducing the increased concentration of atmospheric $\mathrm{CO}_{2}$ as well as generating renewable hydrocarbon fuels that can be directly supplied to our present energy infrastructure (Costentin et al., 2013; Corma and García, 2013; Genevese et al., 2013; Habisreutinger et al., 2013; Indrakanti et al., 2009; Izumi, 2013; Kubacka et al., 2012; Lewis and Nocera, 2006; Lv et al., 2012; Roy et al., 2010). The photocatalytic conversion of $\mathrm{CO}_{2}$ involves two reaction steps:

$$
\begin{aligned}
& 2 \mathrm{H}_{2} \mathrm{O}(\mathrm{g}) \rightarrow 2 \mathrm{H}_{2}(\mathrm{~g})+\mathrm{O}_{2}(\mathrm{~g}), \\
& \Delta G_{r}^{\circ}=689 \mathrm{~kJ} \mathrm{~mol}^{-1} \\
& \mathrm{CO}_{2}(\mathrm{~g})+3 \mathrm{H}_{2}(\mathrm{~g}) \rightarrow \mathrm{CH}_{3} \mathrm{OH}(\mathrm{g})+\mathrm{H}_{2} \mathrm{O}(\mathrm{g}), \\
& \Delta G_{r}^{\circ}=2.9 \mathrm{~kJ} \mathrm{~mol}^{-1}
\end{aligned}
$$

It is important to investigate good catalysts for $\mathrm{CO}_{2}$ conversion into fuels using hydrogen as a reductant (Eq. 2), which is potentially obtained from photocatalytic water splitting (Eq. 1) (Izumi, 2013; Ahmed et al., 2011).

In this study, catalysts for converting $\mathrm{CO}_{2}$ into methanol using hydrogen and UV-visible light were investigated. Layered Double Hydroxides (LDH) $\left[\mathrm{M}^{\mathrm{II}}{ }_{1-x} \mathrm{M}^{\mathrm{III}}{ }_{x}(\mathrm{OH})_{2}\right]^{x+} \mathrm{X}^{2-}{ }_{x / 2} \cdot m \mathrm{H}_{2} \mathrm{O}\left(\mathrm{M}^{\mathrm{II}}=\mathrm{Zn}, \mathrm{Cu} ; \mathrm{M}^{\mathrm{III}}=\mathrm{Al}\right.$, $\left.\mathrm{Ga} ; \mathrm{X}=\mathrm{CO}_{3}, \mathrm{Cu}(\mathrm{OH})_{4} ; m \sim 1 / 2\right)$ were chosen with the expectation of:

- sorption capacity for $\mathrm{CO}_{2}$ in the layered space,

- tunable semiconductor properties as a result of the choice of metal cations

(Ahmed et al., 2013; Cavani et al., 1991; Fan et al., 2014; Li et al., 2014; Sideris et al., 2008; Zümreoglu-Karan and Ay, 2012).
Furthermore, to utilize visible light as the major part of the solar spectrum, dyes/nanoparticles were mixed with the LDH. Especially, the effects of $\mathrm{Cu}$ phthalocyanine tetrasulfonate hydrate $\left(\mathrm{CuPcTs}^{4-}\right)$ combined with $\mathrm{LDH}$ were studied.

\section{EXPERIMENTAL SECTION}

A LDH compound of $\left[\mathrm{Zn}_{3} \mathrm{Ga}(\mathrm{OH})_{8}\right]_{2}^{+} \mathrm{CO}_{3}{ }^{2-} \cdot m \mathrm{H}_{2} \mathrm{O}$ was synthesized using a reported procedure from metal nitrates, $\mathrm{Na}_{2} \mathrm{CO}_{3}$, and $\mathrm{NaOH}$ controlled at $\mathrm{pH} 8$ (Ahmed et al., 2011). This compound is abbreviated as $\mathrm{Zn}_{3} \mathrm{Ga} \mid \mathrm{CO}_{3}$. Similarly, LDH comprising various compositions of $\left[\mathrm{M}_{3}^{\mathrm{II}} \mathrm{M}^{\mathrm{III}}(\mathrm{OH})_{8}\right]_{2}^{+} \mathrm{X}^{2-} \cdot m \mathrm{H}_{2} \mathrm{O}\left(\mathrm{X}=\mathrm{CO}_{3}, \mathrm{Cu}(\mathrm{OH})_{4}\right)$ were synthesized from nitrates of $\mathrm{Zn}, \mathrm{Cu}, \mathrm{Al}$ and $\mathrm{Ga}$, and sodium carbonate/ammonium tetrachlorocuprate dihydrate at $\mathrm{pH} 8$ (Ahmed et al., 2012). The formula is abbreviated as $\mathrm{M}_{3}^{\mathrm{II}} \mathrm{M}^{\mathrm{III}} \mid \mathrm{X}$.

$\mathrm{Na}^{+}{ }_{4} \mathrm{CuPcTs}^{4-}$ was purchased from Aldrich (purity $>85 \%$ ) and used without further purification. For the ion exchange method, we followed the procedure presented in reference (Parida et al., 2007). Firstly, $0.50 \mathrm{~g}$ of $\mathrm{Zn}_{3} \mathrm{Ga} \mid \mathrm{CO}_{3}$ powder was immersed in an aqueous solution of $\mathrm{Na}_{4}^{+}{ }_{4} \mathrm{CuPcTs}^{4-}(0.60 \mathrm{mM}, 25 \mathrm{~mL})$ in a flask and magnetically stirred at 900 rotations per minute (rpm) for $24 \mathrm{~h}$. The blue precipitates that were obtained were filtered using a polytetrafluoroethylene-based membrane filter (Omnipore JGWP04700, Millipore) with a pore size of $0.2 \mu \mathrm{m}$ and washed well with deionized water $\left(<0.06 \mu \mathrm{S} \mathrm{cm}{ }^{-1}\right.$; total $250 \mathrm{~mL}$ ). The precipitates that were obtained were dried under vacuum at $290 \mathrm{~K}$ for $24 \mathrm{~h}$. The blue sample was denoted as CuPcTs- $\mathrm{Zn}_{3} \mathrm{Ga} \mid \mathrm{CO}_{3}$. The loading of $\mathrm{Cu}$ was $0.19 \mathrm{wt} \%$. 
S. Kawamura et al. / Photocatalytic Conversion of Carbon Dioxide Using Zn-Cu-Ga Layered Double Hydroxides Assembled 843 with Cu Phthalocyanine: Cu in Contact with Gaseous Reactant is Needed for Methanol GenerationPhotocatalytic Conversion of Carbon Dioxide Using

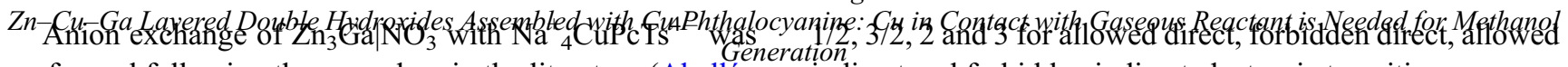
performed following the procedure in the literature (Abellán et al., 2012). All of the procedure until the drying under vacuum was conducted under an argon atmosphere. $0.30 \mathrm{~g}$ of $\mathrm{Zn}_{3} \mathrm{Ga} \mid \mathrm{NO}_{3}$ powder was placed in a flask and an aqueous solution of $\mathrm{Na}^{+}{ }_{4} \mathrm{CuPcTs}^{4-}(5.0 \mathrm{mM}, 200 \mathrm{~mL})$ was slowly added and magnetically stirred at $900 \mathrm{rpm}$. Then, $30 \mathrm{~mL}$ of ethylene glycol and $30 \mathrm{~mL}$ of ethanol were added to the flask. The mixture was agitated by ultrasound $(430 \mathrm{~W}$, $38 \mathrm{kHz}$ ) for $10 \mathrm{~min}$ and then was magnetically stirred at 900 rpm for 3 days.

The precipitates that were obtained were filtered using an Omnipore JGWP04700 filter and washed well with ethanol (total $250 \mathrm{~mL}$ ) and deionized water (total $250 \mathrm{~mL}$ ). The precipitates that were obtained were dried at $290 \mathrm{~K}$ for $24 \mathrm{~h}$ under vacuum. The sample was denoted as $\mathrm{Zn}_{3} \mathrm{Ga} \mid \mathrm{CuPcTs}$.

$\mathrm{Ag}$ nitrate was impregnated from aqueous solution with $\mathrm{Zn}_{3} \mathrm{Ga} \mid \mathrm{CO}_{3}$. The loading of $\mathrm{Ag}$ was $0.36 \mathrm{wt} \%$ (Kawamura et al., 2015). The sample was denoted as $\mathrm{Ag}-\mathrm{Zn}_{3} \mathrm{Ga} \mid \mathrm{CO}_{3}$. Separately, the assembly of $\mathrm{Au}$ nanoparticles with $\mathrm{Zn}_{3} \mathrm{Ga}$ | $\mathrm{CO}_{3}$ was obtained using the structural reconstruction of $\mathrm{LDH}$ in the aqueous solutions containing $\mathrm{Au}^{3+}$ (Carja et al., 2013). Hence, $1.20 \mathrm{~g} \mathrm{Zn}_{3} \mathrm{Ga} \mid \mathrm{CO}_{3}$ powder was calcined in an oven at $773 \mathrm{~K}$ for $8 \mathrm{~h}$. Freshly calcined $\mathrm{Zn}_{3} \mathrm{Ga} \mid \mathrm{CO}_{3}$ powder was directly added to $200 \mathrm{~mL}$ aqueous solution of $\mathrm{Au}$ (III) acetate ( $>99.9 \%$, Alfa Aesar; $0.10 \mathrm{~g}$ ) stirring at a rate of $900 \mathrm{rpm}$. The $\mathrm{pH}$ of the solution was adjusted to 8.0 by the addition of $\mathrm{NaOH}$ aqueous solution $(0.10 \mathrm{M})$. The reaction mixture was stirred at the rate of $900 \mathrm{rpm}$ and $290 \mathrm{~K}$ for $20 \mathrm{~min}$ and at the rate of $150 \mathrm{rpm}$ and $313 \mathrm{~K}$ for $5 \mathrm{~h}$. Then, the precipitate was centrifuged at the rate of $10000 \mathrm{rpm}$ and dried in an oven at $353 \mathrm{~K}$ for $1 \mathrm{~h}$. The color of the catalyst obtained was light purple. The sample was denoted as $\mathrm{Au}-\mathrm{Zn}_{3} \mathrm{Ga} \mid \mathrm{CO}_{3}$.

Optical spectroscopic measurements were performed using a UV-visible spectrophotometer (model V-650, $J A S C O$ ) using $\mathrm{D}_{2}$ and halogen lamps for wavelengths between 200 and $340 \mathrm{~nm}$ and 340 and $800 \mathrm{~nm}$, respectively. An integrating sphere (model ISV-469, JASCO) was used for the Diffuse Reflectance (DR) measurements. The samples were set in contact with the quartz window glass in gas-tight DR cells. Measurements were performed at $290 \mathrm{~K}$ within the wavelength range $200-800 \mathrm{~nm}$ using $70 \mathrm{mg}$ of sample. DR spectra were converted to absorption spectra on the basis of the Kubelka-Munk equation (Ahmed et al., 2011, 2012). The band-gap $\left(E_{\mathrm{g}}\right)$ value was evaluated on the basis of either simple extrapolation of the absorption edge or the fit to the Davis-Mott equation:

$$
\alpha \times h v \propto\left(h v-E_{g}\right)^{n}
$$

in which $\alpha, h$, and $v$ are the absorption coefficient, Planck's constant and the frequency of light, respectively, and $n$ is

indirect and forbidden indirect electronic transitions, respectively (Wooten, 1972).

The Brunauer-Emmett-Teller surface area $\left(S_{\mathrm{BET}}\right)$ was calculated on the basis of eight-point measurements between 10 and $46 \mathrm{kPa}$ in the $\mathrm{N}_{2}$ adsorption isotherm at $77 \mathrm{~K}$. The X-Ray Diffraction (XRD) pattern was observed using a D8 ADVANCE diffractometer (Bruker) at the Center for Analytical Instrumentation, Chiba University, at a Bragg angle of $2 \theta_{\mathrm{B}}=3-60^{\circ}$ with a scan step of $0.01^{\circ}$ and a scan rate of $5 \mathrm{~s}$ per step. The measurements were performed at $40 \mathrm{kV}$ and $40 \mathrm{~mA}$ using $\mathrm{Cu} \mathrm{Ka}$ emission and a nickel filter.

$\mathrm{Cu}$ K-edge X-ray Absorption Fine Structure (XAFS) spectra were measured at $290 \mathrm{~K}$ in transmission mode in the Photon Factory Advanced Ring at the High Energy Accelerator Research Organization (Tsukuba) on beamline NW10A. The storage ring energy was $6.5 \mathrm{GeV}$ and the ring current was 46.6-36.1 mA. A Si (311) double-crystal monochromator and platinum-coated focusing cylindrical mirror were inserted into the X-ray beam path. The X-ray intensity was maintained at $65 \%$ of the maximum flux using a piezo translator set to the crystal. The slit opening size was $1 \mathrm{~mm}$ (vertical) $\times 2 \mathrm{~mm}$ (horizontal) in front of the ionization chamber. Part of the XAFS measurements were performed for a sample in a reactor equipped with polyethylene naphthalate windows (Q51-16, Teijin) irradiated by a xenon arc lamp (Morikawa et al., 2014a; Izumi et al., 2007). The Cu K-edge absorption energy was calibrated to $8980.3 \mathrm{eV}$ for the spectrum of $\mathrm{Cu}$ metal foil (Bearden, 1967).

The XAFS data were analyzed using an XDAP (X-ray absorption fine structure Data Analysis Program) package (Vaarkamp et al., 2006). The pre-edge background was approximated by a modified Victoreen function $C_{2} / E^{2}+C_{1} / E+C_{0}$. The background of the post-edge oscillation was approximated by a smoothing spline function and calculated by an equation for the number of data points, where $k$ is the wavenumber of photoelectrons:

$$
\sum_{\mathrm{i}=1}^{\text {Data Points }} \frac{\left(\mu x_{\mathrm{i}}-B G_{\mathrm{i}}\right)^{2}}{\exp \left(-0.075 k_{\mathrm{i}}^{2}\right)} \leq \text { smoothing factor }
$$

Multiple-shell curve-fit analyses were performed for the Fourier-filtered $k^{3}$-weighted Extended X-ray Absorption Fine Structure (EXAFS) data in $k$ - and $R$-space using empirical amplitude extracted from the EXAFS data for $\mathrm{Na}_{4}^{+}{ }_{4} \mathrm{CuPcTs}^{4-}$ (Izumi et al., 2005, 2009). The interatomic distance $(R)$ and its associated coordination number $(N)$ for the $\mathrm{Cu}-\mathrm{N}$ pair were set to $0.1950 \mathrm{~nm}$ with a $N$ value of 4 (Carrera et al., 2004). The many-body reduction factor $S_{0}^{2}$ was assumed to be equal for both the sample and the reference.

As-synthesized and preheated samples of the $\mathrm{LDH}$ $\mathrm{CuPcTs}-\mathrm{Zn}_{3} \mathrm{Ga}\left|\mathrm{CO}_{3}, \mathrm{Ag}-\mathrm{Zn}_{3} \mathrm{Ga}\right| \mathrm{CO}_{3}$ and $\mathrm{Au}-\mathrm{Zn}_{3} \mathrm{Ga} \mid \mathrm{CO}_{3}$ 
were tested for the photocatalytic conversion of $\mathrm{CO}_{2}$ (Kawamura et al., 2015). The tests were conducted in a closed circulating system (171 $\mathrm{mL})$ equipped with a photoreaction quartz cell that had a flat bottom $\left(23.8 \mathrm{~cm}^{2}\right)$. $100 \mathrm{mg}$ of the LDH catalyst was uniformly spread in the photoreaction cell and was evacuated by rotary and diffusion pumps $\left(10^{-6} \mathrm{~Pa}\right)$ at $290 \mathrm{~K}$ for $2 \mathrm{~h}$ until the desorbed gas was detected by an online Gas Chromatograph (GC). $2.3 \mathrm{kPa}$ of $\mathrm{CO}_{2}(0.177 \mathrm{mmol})$ and $21.7 \mathrm{kPa}$ of $\mathrm{H}_{2}(1.67 \mathrm{mmol})$ were introduced to both intact and pretreated $\mathrm{LDH}$ photocatalysts and were allowed to circulate for $30 \mathrm{~min}$ in contact with the catalyst to attain sorption equilibrium before irradiation.

The photocatalyst was then irradiated with UV-visible light from the 500-W xenon arc lamp (Ushio, model UI-502Q) upward through the flat bottom of the quartz reactor for $5 \mathrm{~h}$. The distance between the bottom of the reactor and the lamp house exit window was set to $20 \mathrm{~mm}$. The light intensity was $42 \mathrm{~mW} \mathrm{~cm}^{-2}$ at the center of the sample cell and $28 \mathrm{~mW}$ $\mathrm{cm}^{-2}$ at the periphery of the bottom plate of the sample cell. The temperature was within the range $305-313 \mathrm{~K}$ at the catalyst position during the illumination for $5 \mathrm{~h}$. As a comparison, the photocatalyst was irradiated with visible light using one of the following UV-cut filters between the light exit of UI-502Q and the photocatalyst. Photocatalytic $\mathrm{CO}_{2}$ reduction tests were performed systematically using L42, Y52, O58, R62, R66 and W-R715 sharp cut filters (Hoya) between the irradiation light exit and photoreactor. The thickness was $2.5 \mathrm{~mm}$ except for W-R715 $(2.0 \mathrm{~mm})$. These filters pass the light of wavelengths greater than 420, 520, 580, 620, 660 and $715 \mathrm{~nm}$, respectively. The transmittance of nonfiltered light was more than $88 \%$ for L42, Y 52, O58, R62 and R66, and almost $100 \%$ for W-R715 (manufacturer's web informa$\left.\operatorname{tion}^{(1)}\right)$. Products and reactants were analyzed using packed columns of a 13X-S molecular sieve and PolyEthylene Glycol (PEG-6000) supported on Flusin P (GL Sciences) set in the online GC equipped with a thermal conductivity detector (Shimadzu, model GC-8A).

The molecular orbitals for $\mathrm{CuPcTs}^{4-}$ were calculated using Gaussian 09 (Gaussian, Inc., Wallingford, Connecticut, USA) employing a polarized basis set of $6-31 \mathrm{G}(\mathrm{d})$ and in density functional theory mode to calculate the electron correlation using the functional B3LYP (Rauf et al., 2012).

\section{RESULTS}

\subsection{Characterization}

The interlayer interval and $S_{\mathrm{BET}}$ of the LDH synthesized were between 0.751-0.792 $\mathrm{nm}$ and $35-70 \mathrm{~m}^{2} \mathrm{~g}^{-1}$,

\footnotetext{
${ }^{1}$ Hoya, web information of sharp cut filters: http://www.hoyaoptics.com/ color filter/sharp cut.htm, http://buyersguide.pennwell.com/Shared/User/ pr9f6c58fbba904eefa88c895cd0f5f336.pdf.
}

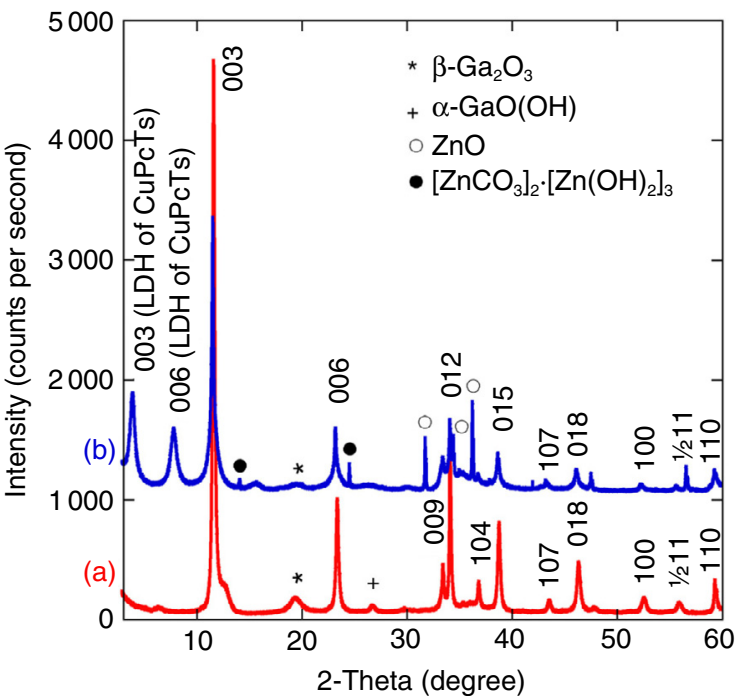

Figure 1

XRD patterns for a) CuPcTs- $\mathrm{Zn}_{3} \mathrm{Ga}_{\mid} \mathrm{CO}_{3}$ and b) $\mathrm{Zn}_{3} \mathrm{Ga} \mid \mathrm{CuPcTs}$.

respectively, except for $\mathrm{Zn}_{3} \mathrm{Ga} \mid \mathrm{CuPcTs}$. The metal cations existed in nearly identical octahedral $\mathrm{MO}_{6}$ coordination environments in cationic sheets based on the similarity of the $\mathrm{Zn} \mathrm{K}, \mathrm{Cu} \mathrm{K}$ and Ga K-edge X-ray Absorption Near-Edge Structure (XANES) (Ahmed et al., 2011, 2012).

The layered structure of the LDH synthesized in this study was confirmed by XRD. The XRD pattern for CuPcTs$\mathrm{Zn}_{3} \mathrm{Ga} \mid \mathrm{CO}_{3}$ is depicted in Figure 1a. The diffraction peaks at $2 \theta_{\mathrm{B}}=11.7^{\circ}, 23.4^{\circ}, 33.5^{\circ}, 34.2^{\circ}, 36.9^{\circ}, 38.8^{\circ}, 43.6^{\circ}$, $46.4^{\circ}, 52.6^{\circ}, 56.9^{\circ}$ and $59.4^{\circ}$ were assigned to $(003)$, (006), (009), (012), (104), (015), (107), (018), (100), ( $\left.\frac{1}{2} 11\right)$ $[=(01 \overline{1} 1)]$ and (110) diffraction, respectively, for the regular layered structure of the $\mathrm{LDH}$. The interlayer interval value was evaluated at $0.755 \mathrm{~nm}$ on the basis of the (003) diffraction angle and changed negligibly as compared with $\mathrm{Zn}_{3} \mathrm{Ga}$ | $\mathrm{CO}_{3}(0.751 \mathrm{~nm}$; Ahmed et al., 2011).

The pattern is compared with that for $\mathrm{Zn}_{3} \mathrm{Ga} \mid \mathrm{CuPcTs}$ (Fig. 1b-line). Two peaks at $2 \theta_{\mathrm{B}}=4.04^{\circ}$ and $7.91^{\circ}$ appeared assignable to (003) and (006) diffraction of the LDH with the interlayer anions of CuPcTs ${ }^{4-}$ (Abellán et al., 2012). The interlayer interval value was evaluated at $2.18 \mathrm{~nm}$ on the basis of the (003) diffraction angle due to the intercalation of larger $\mathrm{CuPcTs}^{4-}$ anions. The diffraction peaks at $2 \theta_{\mathrm{B}}=$ $11.6^{\circ}, 23.3^{\circ}, 33.5^{\circ}, 34.2^{\circ}, 36.3^{\circ}, 38.7^{\circ}, 43.2^{\circ}, 46.2^{\circ}$, $52.3^{\circ}, 56.6^{\circ}$ and $59.3^{\circ}$ also appeared, and suggested the by-product phase of $\mathrm{Zn}_{3} \mathrm{Ga} \mid \mathrm{CO}_{3}$. The interlayer interval value was evaluated at $0.760 \mathrm{~nm}$ on the basis of the (003) diffraction angle for the by-product phase.

In the pattern for both samples, a very small amount of impurity peaks was observed at $19.5-19.6^{\circ}$ and $26.8^{\circ}$ owing 
S. Kawamura et al. / Photocatalytic Conversion of Carbon Dioxide Using Zn-Cu-Ga Layered Double Hydroxides Assembled 845 with $\mathrm{Cu}$ Phthalocyanine: $\mathrm{Cu}$ in Contact with Gaseous Reactant is Needed for Methanol GenerationPhotocatalytic Conversion of Carbon Dioxide Using

Zn-Cu-Ga Layered Double HXgbiaxides Assembled with Cu Phthalocyanine: Cu in

The band-gap values and the type of electronic transition based on Generation UV-visible spectra for $\mathrm{Zn}-\mathrm{Cu}-\mathrm{Ga} \mathrm{LDH}$

\begin{tabular}{c|c|c}
\hline Photocatalyst & Band gap (eV) & $e^{-}$transition \\
\hline $\mathrm{Zn}_{3} \mathrm{Ga} \mid \mathrm{CO}_{3}$ & 5.6 & Direct \\
\hline $\mathrm{Zn}_{1.5} \mathrm{Cu}_{1.5} \mathrm{Ga} \mid \mathrm{CO}_{3}$ & 3.5 & Forbidden direct \\
\hline $\mathrm{Zn}_{3} \mathrm{Al} \mid \mathrm{CO}_{3}$ & 5.7 & Direct \\
\hline $\mathrm{Zn}_{1.5} \mathrm{Cu}_{1.5} \mathrm{Al} \mid \mathrm{CO}_{3}$ & 4.1 & Direct \\
\hline $\mathrm{Zn}_{3} \mathrm{Ga} \mid \mathrm{Cu}(\mathrm{OH})_{4}$ & 4.2 (impurity phase: 3.2$)$ & Direct \\
\hline $\mathrm{Zn}_{1.5} \mathrm{Cu}_{1.5} \mathrm{Ga} \mid \mathrm{Cu}(\mathrm{OH})_{4}$ & 3.0 & Direct \\
\hline
\end{tabular}

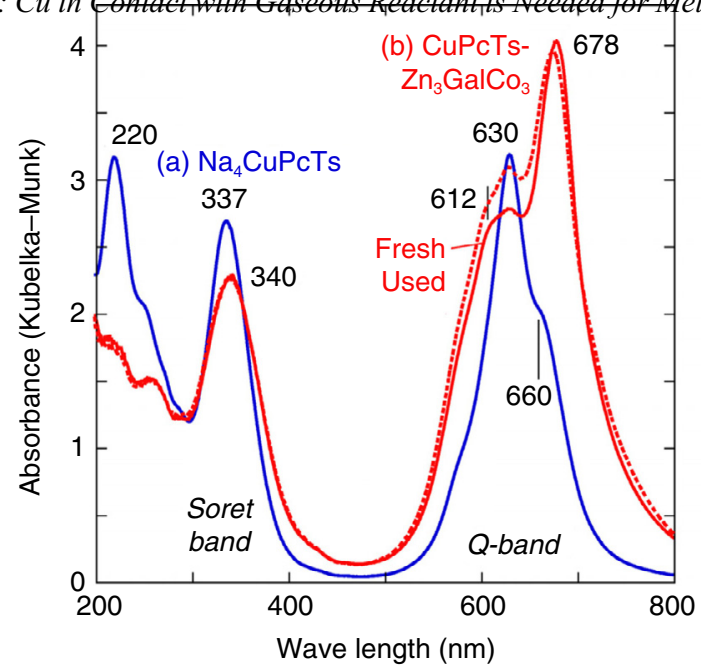

to $\beta-\mathrm{Ga}_{2} \mathrm{O}_{3}$ and $\alpha-\mathrm{GaO}(\mathrm{OH})$, respectively (Fig. 1). In the pattern for $\mathrm{Zn}_{3} \mathrm{Ga} \mid \mathrm{CuPcTs}$, a small amount of impurity peaks at $31.9^{\circ}, 34.5^{\circ}$ and $36.3^{\circ}$ owing to $\mathrm{ZnO}$ and those at $14.2^{\circ}$ and $24.6^{\circ}$ owing to $\left[\mathrm{ZnCO}_{3}\right]_{2} \cdot\left[\mathrm{Zn}(\mathrm{OH})_{2}\right]_{3}$ also appeared (b-line).

The $E_{\mathrm{g}}$ values were evaluated by the extrapolation of the absorption edge in the UV-visible spectra. The values given were within the range 5.6-3.0 eV for $\mathrm{Zn}_{3} \mathrm{Ga} \mid \mathrm{CO}_{3}$, $\mathrm{Zn}_{1.5} \mathrm{Cu}_{1.5} \mathrm{Ga}\left|\mathrm{CO}_{3}, \quad \mathrm{Zn}_{3} \mathrm{Al}\right| \mathrm{CO}_{3}, \quad \mathrm{Zn}_{1.5} \mathrm{Cu}_{1.5} \mathrm{Al} \mid \mathrm{CO}_{3}$, $\mathrm{Zn}_{3} \mathrm{Ga} \mid \mathrm{Cu}(\mathrm{OH})_{4}$ and $\mathrm{Zn}_{1.5} \mathrm{Cu}_{1.5} \mathrm{Ga} \mid \mathrm{Cu}(\mathrm{OH})_{4}$ (Tab. 1).

Besides the absorption edge for the $\mathrm{LDH}$, an intense absorption peak appeared at $678 \mathrm{~nm}$ for CuPcTs- $\mathrm{Zn}_{3} \mathrm{Ga}$ | $\mathrm{CO}_{3}$ (Fig. 2b-line, solid line). The UV-visible spectrum for CuPcTs- $\mathrm{Zn}_{3} \mathrm{Ga} \mid \mathrm{CO}_{3}$ basically resembled that for aqueous solution of $\mathrm{Na}_{4}^{+}{ }_{4} \mathrm{CuPcTs}^{4-}$ (Fig. 2a-line); however, the peak intensity ratio in the range $600-700 \mathrm{~nm}$ was different: $678 \mathrm{~nm}(\mathrm{~s}), 630 \mathrm{~nm}(\mathrm{sh})$ and $612 \mathrm{~nm}(\mathrm{sh})$ for CuPcTs$\mathrm{Zn}_{3} \mathrm{Ga} \mid \mathrm{CO}_{3}$ versus $630 \mathrm{~nm}$ (s) and $660 \mathrm{~nm}(\mathrm{sh})$ for aqueous solution of $\mathrm{Na}_{4}^{+} \mathrm{CuPcTs}^{4-}$. As the peaks at $678-660 \mathrm{~nm}$ or $630 \mathrm{~nm}$ would be assigned to HOMO $\left(\mathrm{a}_{1 \mathrm{u}}\right)$-LUMO $\left(\mathrm{e}_{\mathrm{g}}\right)$ electronic transition (Q-band, Fig. 3), the HOMO and/or LUMO of $\mathrm{CuPcTs}^{4-}$ were significantly perturbed by the interaction with the $\mathrm{Zn}_{3} \mathrm{Ga} \mid \mathrm{CO}_{3}$ surface.

As compared with the Q-band, the peaks at $337-340 \mathrm{~nm}$ were assigned to transition from $\mathrm{a}_{2 \mathrm{u}}$ to LUMO $\left(\mathrm{e}_{\mathrm{g}}\right)$ (Soret band). The peak at $220 \mathrm{~nm}$ was only observed for aqueous solution of $\mathrm{Na}_{4}^{+} \mathrm{CuPcTs}^{4-}$ (Fig. 2a-line). This peak would be a transition from a slightly deeper level than $\mathrm{a}_{2 \mathrm{u}}$ to LUMO $\left(e_{g}\right)$ or from $a_{2 u}$ to a slightly shallower level than LUMO (e $\mathrm{e}_{\mathrm{g}}$ (Marom et al., 2008).

The UV-visible spectrum for CuPcTs- $\mathrm{Zn}_{3} \mathrm{Ga} \mid \mathrm{CO}_{3}$ used for photocatalytic tests under $\mathrm{CO}_{2}+\mathrm{H}_{2}$ for $5 \mathrm{~h}$ was also measured (Fig. 2b-line, dotted line). The spectrum was essentially identical to that for the fresh sample (solid line), indicating the stability of $\mathrm{CuPcTs}^{4-}$ dispersed over $\mathrm{Zn}_{3} \mathrm{Ga}$ | $\mathrm{CO}_{3}$ under the photocatalytic reaction conditions.

Figure 2

Diffuse-reflectance UV-visible absorption spectra for aqueous solution of a) $\mathrm{Na}_{4}^{+}{ }_{4} \mathrm{CuPcTs}^{4-}\left(6.0 \mu \mathrm{mol} \mathrm{L} \mathrm{L}^{-1}\right)$ and b) CuPcTs- $\mathrm{Zn}_{3} \mathrm{Ga} \mid \mathrm{CO}_{3}$. Solid line: fresh sample and dotted line: sample used after the photocatalytic test for $5 \mathrm{~h}$.

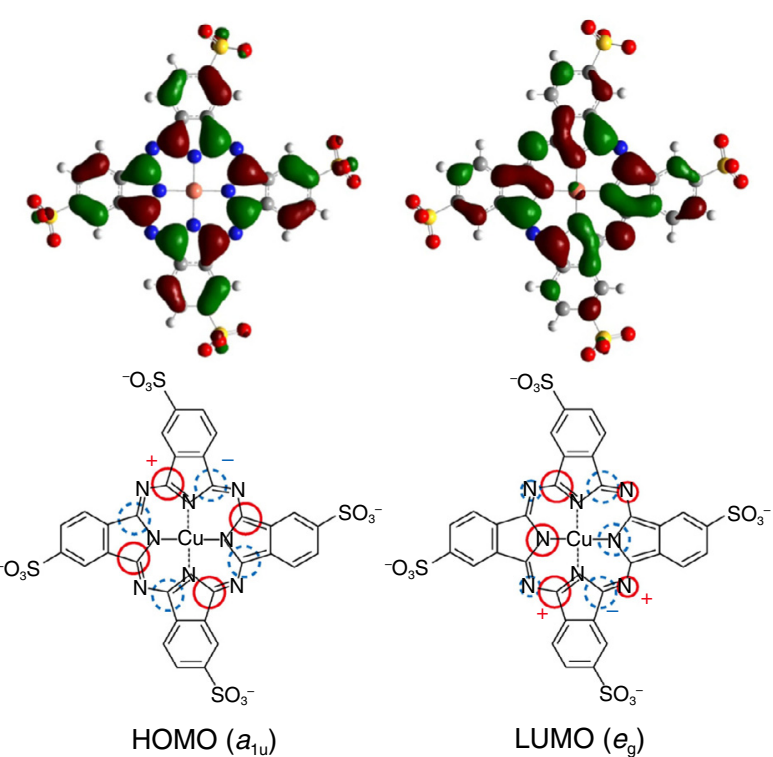

Figure 3

HOMO and LUMO for $\mathrm{Na}_{4}^{+} \mathrm{CuPcTs}^{4-}$ calculated using Gaussian 09 .

$\mathrm{Ag}-\mathrm{Zn}_{3} \mathrm{Ga} \mid \mathrm{CO}_{3}$ and $\mathrm{Au}-\mathrm{Zn}_{3} \mathrm{Ga} \mid \mathrm{CO}_{3}$ exhibited a major absorption peak at 411 and $555 \mathrm{~nm}$, respectively (not shown). These peaks are ascribed to Surface Plasmonic Resonance (SPR) of Ag and Au metallic nanoparticles. 
The XANES spectra for $\mathrm{Na}_{4}^{+} \mathrm{CuPcTs}^{4-}$ and CuPcTs$\mathrm{Zn}_{3} \mathrm{Ga} \mid \mathrm{CO}_{3}$ are shown in Figure 4. The whole spectrum pattern changed negligibly by the dispersion of $\mathrm{CuPcTs}^{4-}$ over the $\mathrm{Zn}_{3} \mathrm{Ga} \mid \mathrm{CO}_{3}$ surface as compared with

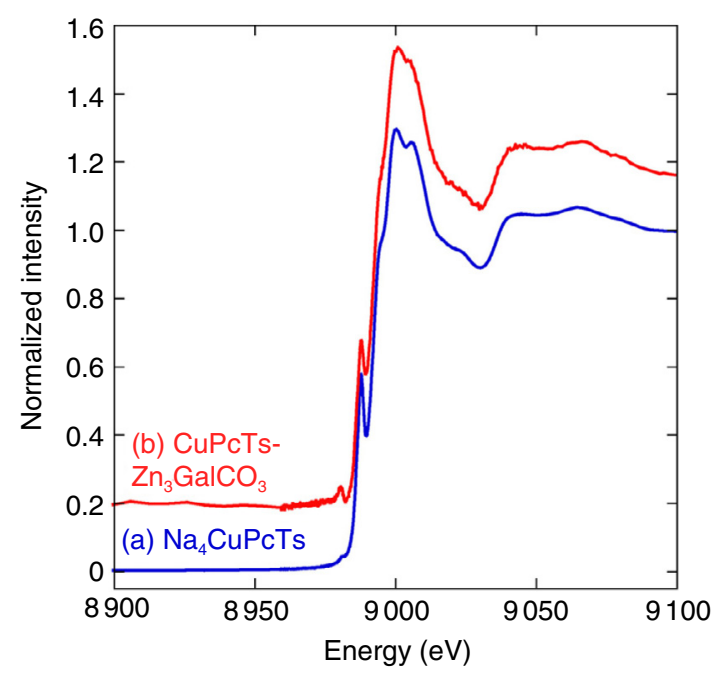

Figure 4

Normalized Cu K-edge XANES spectra for a) $\mathrm{Na}_{4}^{+} \mathrm{CuPcTs}^{4-}$ diluted by boron nitride and b) CuPcTs- $\mathrm{Zn}_{3} \mathrm{Ga}_{2} \mathrm{CO}_{3}$.
$\mathrm{Na}^{+}{ }_{4} \mathrm{CuPcTs}^{4-}$ crystallines, suggesting that the framework structure of $\mathrm{CuPcTs}^{4-}$ was retained upon the dispersion over the $\mathrm{Zn}_{3} \mathrm{Ga} \mid \mathrm{CO}_{3}$ surface. In contrast, a sharp shoulder peak at $8988 \mathrm{eV}$ became relatively weaker upon the dispersion over the LDH surface. This may be related to the perturbation of LUMO by the interaction with the LDH surface based on UV-visible spectrum change (Fig. 2).

The 1s-3d electronic transition peak appeared at $8982 \mathrm{eV}$ for both $\mathrm{Na}_{4}^{+} \mathrm{CuPcTs}^{4-}$ and CuPcTs- $\mathrm{Zn}_{3} \mathrm{Ga} \mid \mathrm{CO}_{3}$ (Fig. 5-I). The transition is allowed for the $\mathrm{Cu}^{\mathrm{II}}$ state of the $3 \mathrm{~d}^{9}$ configuration, whereas the peak disappeared for the $\mathrm{Cu}^{\mathrm{I}}$ state of the $3 \mathrm{~d}^{10}$ configuration (Morikawa et al., 2014a). Utilizing this difference, the reduction of $\mathrm{Cu}^{\mathrm{II}}$ sites in $\mathrm{Na}_{4}^{+}{ }_{4} \mathrm{CuPcTs}^{4-}$ and $\mathrm{CuPcTs}-\mathrm{Zn}_{3} \mathrm{Ga} \mid \mathrm{CO}_{3}$ was monitored irradiated by UVvisible light.

The $\mathrm{Cu}$ amount in $\mathrm{Na}^{+}{ }_{4} \mathrm{CuPcTs}^{4-}$ charged was $118 \mu \mathrm{mol}$. The decreasing rate of the $1 \mathrm{~s}-3 \mathrm{~d}$ peak irradiated by UVvisible light for $64 \mathrm{~min}$ was $18.0 \% \mathrm{~h}^{-1}$ or $21.2 \mu \mathrm{mol} \mathrm{h}^{-1}$. In contrast, the $\mathrm{Cu}$ amount in $\mathrm{CuPcTs}-\mathrm{Zn}_{3} \mathrm{Ga} \mid \mathrm{CO}_{3}$ charged was $13.5 \mu \mathrm{mol}$. The decreasing rate of the $1 \mathrm{~s}-3 \mathrm{~d}$ peak irradiated by UV-visible light for $180 \mathrm{~min}$ was $20.2 \% \mathrm{~h}^{-1}$ or $2.72 \mu \mathrm{mol} \mathrm{h}^{-1}$ (Fig. 5-II). The photoreduction to the $\mathrm{Cu}(\mathrm{I})$ state was slightly faster for $\mathrm{CuPcTs}-\mathrm{Zn}_{3} \mathrm{Ga}_{\mid} \mathrm{CO}_{3}$ than for $\mathrm{Na}_{4}^{+} \mathrm{CuPcTs}^{4-}$; however, exact comparison of the diffusion rates of photogenerated electrons to the $\mathrm{Cu}(\mathrm{II})$ site (Morikawa et al., 2014a) was difficult in this case
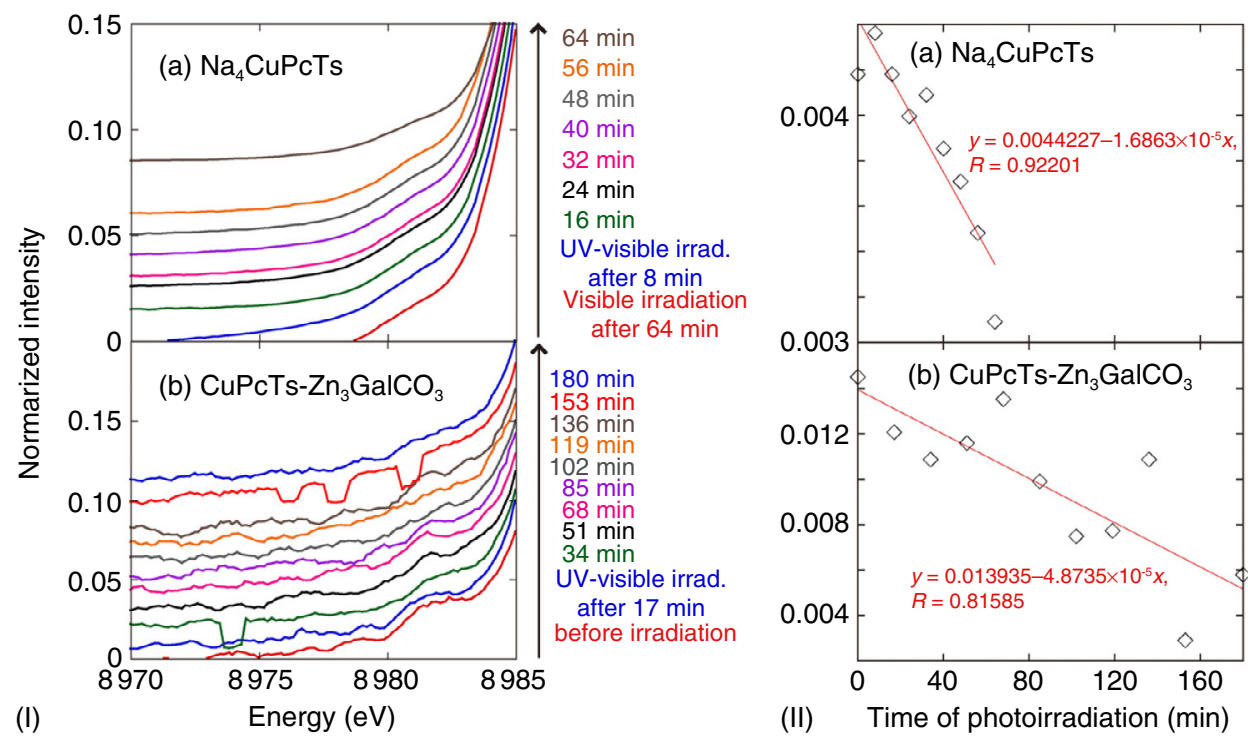

Figure 5

I) Expanded view of the $1 \mathrm{~s}-3 \mathrm{~d}$ pre-edge peak region of normalized $\mathrm{Cu}$ K-edge XANES spectra of a) $\mathrm{Na}_{4}^{+} \mathrm{CuPcTs}^{4-}$ under vacuum and b) CuPcTs- $\mathrm{Zn}_{3} \mathrm{Ga} \mid \mathrm{CO}_{3}$ under $\mathrm{CO}_{2}(2.3 \mathrm{kPa})+\mathrm{H}_{2}(21.7 \mathrm{kPa})$ and UV-visible light irradiation. II) Time course of the $1 \mathrm{~s}-3 \mathrm{~d}$ peak intensity for the two samples. The amount of $\mathrm{Na}^{+}{ }_{4} \mathrm{CuPcTs}^{4-}$ and $\mathrm{CuPcTs}-\mathrm{Zn}_{3} \mathrm{Ga}_{\mid} \mathrm{CO}_{3}$ charged in the photoreaction cell was 116 and $401 \mathrm{mg}$, respectively. 
S. Kawamura et al. / Photocatalytic Conversion of Carbon Dioxide Using Zn-Cu-Ga Layered Double Hydroxides Assembled 847 with Cu Phthalocyanine: Cu in Contact with Gaseous Reactant is Needed for Methanol GenerationPhotocatalytic Conversion of Carbon Dioxide Using

Zn-Cu-Ga Layered Double Hydroxides Assembled with $\uparrow_{5} u$ Phthalocyanine: Cu in Contact with Gaseous Reactant is Needed for Methanol

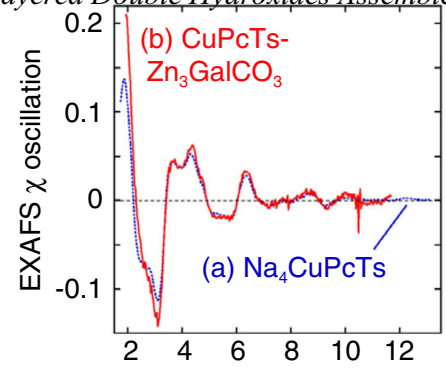

A)
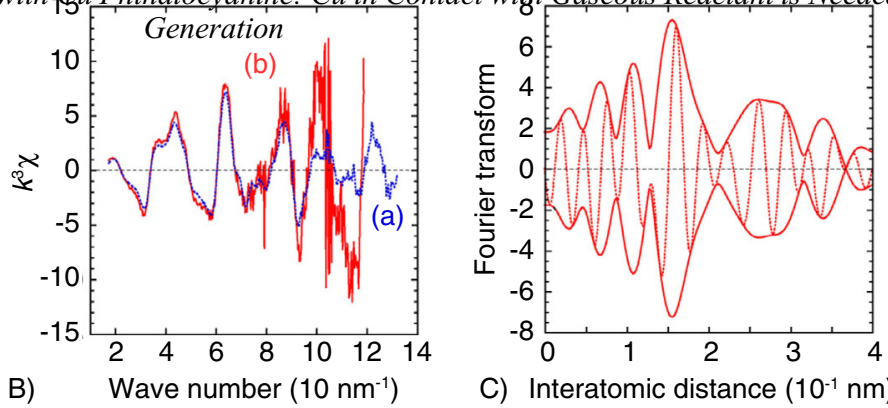

C) Interatomic distance $\left(10^{-1} \mathrm{~nm}\right)$
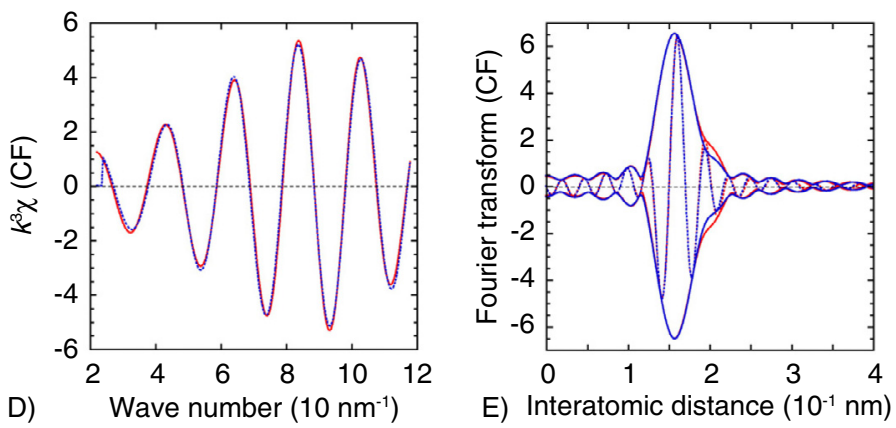

Figure 6

A) $\mathrm{Cu}$ K-edge EXAFS $\chi$ oscillation and B) $k^{3}$-weighted EXAFS $\chi$ oscillation for $\mathrm{Na}_{4}{ }_{4} \mathrm{CuPcTs}^{4-}$ diluted by boron nitride (a) and $\mathrm{CuPcTs}-\mathrm{Zn}_{3} \mathrm{Ga} \mid \mathrm{CO}_{3}$ (b), C) its associated Fourier transform, and D, E) best-fit results in $k$-space D) and $R$-space $\mathrm{E}$ ) for $\mathrm{CuPcTs}-\mathrm{Zn}_{3} \mathrm{Ga}_{\mid} \mathrm{CO}_{3}$. Solid line: magnitude and dotted line: imaginary part C, E). Red (thick) line: experimental and blue (thin) line: fit D, E).

due to the difference in the shape and light absorbance of the samples: dense crystallines of $\mathrm{Na}_{4}^{+} \mathrm{CuPcTs}^{4-}$ versus fine powder of CuPcTs- $\mathrm{Zn}_{3} \mathrm{Ga} \mid \mathrm{CO}_{3}$. At least, as the UV-visible light absorbance was apparently higher for $\mathrm{Na}_{4}^{+} \mathrm{CuPcTs}^{4-}$, the possibility of faster electron accumulation for CuPcTs$\mathrm{Zn}_{3} \mathrm{Ga} \mid \mathrm{CO}_{3}$ than $\mathrm{Na}^{+}{ }_{4} \mathrm{CuPcTs}^{4-}$ is high due to the injection of excited electrons in $\mathrm{Zn}_{3} \mathrm{Ga} \mid \mathrm{CO}_{3}$ irradiated by $\mathrm{UV}$ light into $\mathrm{CuPcTs}^{4-}$ at the surface.

The EXAFS $\chi$ oscillation changed negligibly when $\mathrm{Na}^{+}{ }_{4} \mathrm{CuPcTs}^{4-}$ was dispersed over the $\mathrm{Zn}_{3} \mathrm{Ga} \mid \mathrm{CO}_{3}$ surface (Fig. 6A). This fact supported the retention of the $\mathrm{CuPcTs}^{4-}$ framework over that of the $\mathrm{Zn}_{3} \mathrm{Ga} \mid \mathrm{CO}_{3}$ suggested by XANES. The curve-fit results for the $\mathrm{Cu}-\mathrm{N}$ interatomic pair provided a distance of $0.198 \mathrm{~nm}$ (fit error $\pm 0.011 \mathrm{~nm}$ ) with a $N$ value of 3.3 (fit error \pm 1.3 ) (Fig. 6D, E).

\subsection{Photocatalytic Tests under $\mathrm{CO}_{2}+\mathrm{H}_{2}$}

In the photocatalytic reaction tests under $\mathrm{CO}_{2}+\mathrm{H}_{2}$ irradiated by UV-visible light, $\mathrm{Zn}_{3} \mathrm{Ga} \mid \mathrm{CO}_{3}$ produced $\mathrm{CO}$ and methanol (Tab. 2A, entry a). Using $\mathrm{Zn}_{1.5} \mathrm{Cu}_{1.5} \mathrm{Ga} \mid \mathrm{CO}_{3}$, the methanol formation rate increased by a factor of 3.3 (Tab. 2A entry g). $\mathrm{Zn}_{3} \mathrm{Al} \mid \mathrm{CO}_{3}$ was more active than $\mathrm{Zn}_{3} \mathrm{Ga} \mid \mathrm{CO}_{3}$, but the major product was $\mathrm{CO}$ (entry h). When $\mathrm{Zn}_{1.5} \mathrm{Cu}_{1.5} \mathrm{Al} \mid \mathrm{CO}_{3}$ was compared with $\mathrm{Zn}_{3} \mathrm{Al} \mid \mathrm{CO}_{3}$, the methanol formation rate was promoted by a factor of 3.3 (Tab. $2 \mathrm{~b}$ entry i) similarly to the $\mathrm{Cu}$ substitution into $\mathrm{Zn}_{3} \mathrm{Ga} \mid \mathrm{CO}_{3}$. The methanol formation rate using $\mathrm{Zn}_{3} \mathrm{Ga} \mid \mathrm{Cu}(\mathrm{OH})_{4}$ was enhanced by a factor of 5.9 compared with $\mathrm{Zn}_{3} \mathrm{Ga} \mid \mathrm{CO}_{3}$ (Tab.2A entries a, j). The methanol selectivity was nearly the same as that obtained with $\mathrm{Zn}_{1.5} \mathrm{Cu}_{1.5} \mathrm{Ga} \mid \mathrm{CO}_{3}$ (71-68 mol\%). Using $\mathrm{Zn}_{1.5} \mathrm{Cu}_{1.5} \mathrm{Ga} \mid$ $\mathrm{Cu}(\mathrm{OH})_{4}$, the methanol formation rate and selectivity were further improved to $0.49 \mu \mathrm{mol} \mathrm{h}{ }^{-1} \mathrm{~g}_{\mathrm{cat}}{ }^{-1}$ and $88 \mathrm{~mol} \%$ (Tab. 2A entry k).

The results in Table 2 were independently reported in this study and references (Ahmed et al., 2011, 2012; Kawamura et al., 2015). However, the rates and selectivity are comparable because common reaction apparatus connected to common online GC were used in these studies. The reproducibility of rates was checked for $\mathrm{Zn}_{3} \mathrm{Ga} \mid \mathrm{CO}_{3}$ in this study and references (Ahmed et al., 2011, 2012; Kawamura et al., 2015), and the variation of formation rates of methanol and $\mathrm{CO}$ was always within $5 \%$.

Furthermore, we reported control reaction tests in darkness, in the absence of a photocatalyst, and in the absence of $\mathrm{CO}_{2}$. No products were found in these control tests except 
TABLE 2

Photocatalytic rates of $\mathrm{CO}_{2}$ reduction with $\mathrm{H}_{2}$ using $\mathrm{LDH}^{(a)}$

\begin{tabular}{|c|c|c|c|c|c|c|}
\hline \multirow[t]{2}{*}{ Entry } & \multirow[t]{2}{*}{ Photocatalyst } & \multicolumn{3}{|c|}{ Formation rate $\left(\mathrm{nmol}^{-1} \mathrm{~g}_{\text {cat }}\right)$} & \multirow{2}{*}{$\begin{array}{c}\text { Selectivity to } \\
\mathrm{CH}_{3} \mathrm{OH}(\mathrm{mol} \%)\end{array}$} & \multirow[t]{2}{*}{ Reference } \\
\hline & & $\mathrm{CH}_{3} \mathrm{OH}$ & $\mathrm{CO}$ & $\Sigma$ & & \\
\hline \multicolumn{7}{|c|}{ A) Irradiated by UV-visible light } \\
\hline a & $\mathrm{Zn}_{3} \mathrm{Ga} \mid \mathrm{CO}_{3}$ & 51 & 80 & 130 & 39 & Ahmed et al. (2011) \\
\hline $\mathrm{b}$ & CuPcTs- $\mathrm{Zn}_{3} \mathrm{Ga} \mid \mathrm{CO}_{3}$ & 96 & 106 & 202 & 48 & This work \\
\hline$b^{\prime}$ & CuPcTs $\& \mathrm{Zn}_{3} \mathrm{Ga} \mid \mathrm{CO}_{3}{ }^{(b)}$ & 28 & 41 & 69 & 41 & This work \\
\hline $\mathrm{c}$ & $\mathrm{Zn}_{3} \mathrm{Ga} \mid \mathrm{CuPcTs}$ & $<4$ & 69 & 69 & $<5$ & This work \\
\hline $\mathrm{d}$ & $\mathrm{Na}_{4} \mathrm{CuPcTs}^{4-}$ & $<4$ & 38 & 38 & $<9.5$ & This work \\
\hline e & $\mathrm{Ag}-\mathrm{Zn}_{3} \mathrm{Ga} \mid \mathrm{CO}_{3}$ & 118 & 102 & 220 & 54 & Kawamura et al. (2015) \\
\hline $\mathrm{f}$ & $\mathrm{Au}-\mathrm{Zn}_{3} \mathrm{Ga} \mid \mathrm{CO}_{3}{ }^{(c)}$ & 30 & 201 & 231 & 13 & Kawamura et al. (2015) \\
\hline $\mathrm{g}$ & $\mathrm{Zn}_{1.5} \mathrm{Cu}_{1.5} \mathrm{Ga} \mid \mathrm{CO}_{3}$ & 170 & 79 & 250 & 68 & Ahmed et al. (2011) \\
\hline $\mathrm{h}$ & $\mathrm{Zn}_{3} \mathrm{Al} \mid \mathrm{CO}_{3}$ & 39 & 620 & 660 & 5.9 & Ahmed et al. (2011) \\
\hline $\mathrm{i}$ & $\mathrm{Zn}_{1.5} \mathrm{Cu}_{1.5} \mathrm{Al} \mid \mathrm{CO}_{3}$ & 130 & 370 & 500 & 26 & Ahmed et al. (2011) \\
\hline $\mathrm{j}$ & $\mathrm{Zn}_{3} \mathrm{Ga} \mid \mathrm{Cu}(\mathrm{OH})_{4}$ & 300 & 130 & 430 & 71 & Ahmed et al. (2012) \\
\hline $\mathrm{k}$ & $\mathrm{Zn}_{1.5} \mathrm{Cu}_{1.5} \mathrm{Ga} \mid \mathrm{Cu}(\mathrm{OH})_{4}$ & 490 & 70 & 560 & 88 & Ahmed et al. (2012) \\
\hline
\end{tabular}

B) Irradiated by visible light $(\lambda>420 \mathrm{~nm})$

\begin{tabular}{c|c|c|c|c|c|c}
\hline $\mathrm{a}$ & $\mathrm{Zn}_{3} \mathrm{Ga} \mid \mathrm{CO}_{3}$ & $<4$ & $<8$ & $<12$ & $<33$ & Ahmed et al. (2011) \\
\hline $\mathrm{b}$ & $\mathrm{CuPcTs}-\mathrm{Zn}_{3} \mathrm{Ga} \mid \mathrm{CO}_{3}$ & 75 & 74 & 148 & 51 & This work \\
\hline $\mathrm{c}$ & $\mathrm{Zn}_{3} \mathrm{Ga} \mid \mathrm{CuPcTs}$ & $<4$ & 33 & 33 & $<11$ & This work \\
\hline $\mathrm{d}$ & $\mathrm{Ag}-\mathrm{Zn}_{3} \mathrm{Ga} \mid \mathrm{CO}_{3}$ & 36 & 88 & 124 & 29 & Kawamura et al. (2015) \\
\hline $\mathrm{e}$ & $\mathrm{Au}-\mathrm{Zn}_{3} \mathrm{Ga} \mid \mathrm{CO}_{3}^{(c)}$ & $<4$ & $<8$ & $<12$ & $<33$ & Kawamura et al. (2015) \\
\hline
\end{tabular}

${ }^{a}$ In $\mathrm{CO}_{2}(2.3 \mathrm{kPa})+\mathrm{H}_{2}(21.7 \mathrm{kPa})$. The catalyst amount was $100 \mathrm{mg}$.

${ }^{b}$ Physical mixture with the weight ratio of 3:97.

${ }^{c}$ Preheated at $373 \mathrm{~K}$ for $30 \mathrm{~min}$.

for water from the interlayer space of the $\mathrm{LDH}$. When the reactant was switched from $\mathrm{CO}_{2}$ to $\mathrm{CO}_{2}+\mathrm{H}_{2}$, methanol and $\mathrm{CO}$ began to evolve using $\mathrm{Zn}_{1.5} \mathrm{Cu}_{1.5} \mathrm{Ga} \mid \mathrm{CO}_{3}$ (Ahmed et al., 2011). When the $\mathrm{Zn}_{1.5} \mathrm{Cu}_{1.5} \mathrm{Ga} \mathrm{CO}_{3}$ and $\mathrm{Zn}_{1.5} \mathrm{Cu}_{1.5} \mathrm{Ga} \mid \mathrm{Cu}(\mathrm{OH})_{4}$ photocatalysts were recycled four times (in total $20 \mathrm{~h}$ of reaction), the methanol and $\mathrm{CO}$ formation continued and the selectivity was kept at $68-57 \mathrm{~mol} \%$ and 76-84 mol\%, respectively (Ahmed et al., 2011, 2013).

The addition of $\mathrm{CuPcTs}^{4-}$ to $\mathrm{Zn}_{3} \mathrm{Ga}_{\mid} \mathrm{CO}_{3}$ improved the total (methanol and $\mathrm{CO}$ ) formation rates by a factor of 1.6 and the methanol selectivity increased to $48 \mathrm{~mol} \%$ (Tab. 2A entry b; Fig. 7a-line). The formation of $\mathrm{CO}$ and methanol continued for more than $5 \mathrm{~h}$, demonstrating the stability of dispersed $\mathrm{CuPcTs}^{4-}$ over the LDH irradiated by UV -visible light under $\mathrm{CO}_{2}+\mathrm{H}_{2}$. In contrast, the performance of $\mathrm{Zn}_{3} \mathrm{Ga} \mid \mathrm{CuPcTs}$ was lower than that of $\mathrm{Zn}_{3} \mathrm{Ga} \mid \mathrm{CO}_{3}$ (Tab. 2A entry c and Fig. 7b-line). It should be noted that unsupported $\mathrm{Na}_{4}^{+} \mathrm{CuPcTs}^{4-}$ generated $\mathrm{CO}$ at a rate of $48 \%$ of that using $\mathrm{Zn}_{3} \mathrm{Ga} \mid \mathrm{CO}_{3}$ (Tab. 2A entry d).

In a control kinetic test using the physical mixture of $3.0 \mathrm{wt} \%$ of $\mathrm{Na}^{+}{ }_{4} \mathrm{CuPcTs}^{4-}$ and $97 \mathrm{wt} \%$ of $\mathrm{Zn}_{3} \mathrm{Ga} \mid \mathrm{CO}_{3}$ $\mathrm{LDH}$ prepared by mixing using a mortar and pestle for 30 min, the formation rates of $\mathrm{CO}$ and methanol were 41 and $28 \mu \mathrm{mol} \mathrm{h}^{-1} \mathrm{~g}_{\text {cat }}{ }^{-1}$, respectively (Tab. 2A entry b), suggesting the importance of close contact of $\mathrm{CuPcTs}^{4-}$ with the $\mathrm{LDH}$ surface for the $\mathrm{CO}_{2}$ photoconversion using $\mathrm{CuPcTs}-\mathrm{Zn}_{3} \mathrm{Ga} \mid \mathrm{CO}_{3}$ (Fig. 7a-line).

The addition of $\mathrm{Ag}$ to $\mathrm{Zn}_{3} \mathrm{Ga} \mid \mathrm{CO}_{3}$ similarly affected the addition of $\mathrm{CuPcTs}^{4-}$. Total formation rates increased by a factor of 1.7 compared with $\mathrm{Zn}_{3} \mathrm{Ga} \mid \mathrm{CO}_{3}$ and methanol 
S. Kawamura et al. / Photocatalytic Conversion of Carbon Dioxide Using Zn-Cu-Ga Layered Double Hydroxides Assembled 849 with Cu Phthalocyanine: Cu in Contact with Gaseous Reactant is Needed for Methanol GenerationPhotocatalytic Conversion of Carbon Dioxide Using

$\mathrm{Zn}-\mathrm{Cu}-\mathrm{Ga}$ Eujered Double Hydroxides Assembled with Cu Phthalocyanine: Cu in Contact with Gaseous Reactant is Needed for Methanol

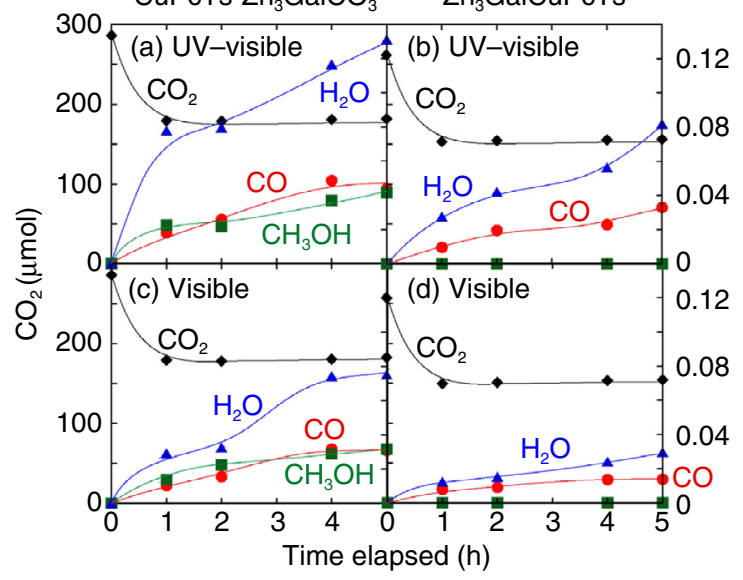

Figure 7

Time course of photocatalytic tests under $\mathrm{CO}_{2}(2.3 \mathrm{kPa})$ and $\mathrm{H}_{2}$ (21.7 kPa) using UV-visible light and a) CuPcTs- $\mathrm{Zn}_{3} \mathrm{Ga}$ | $\mathrm{CO}_{3}$ and b) $\mathrm{Zn}_{3} \mathrm{Ga} \mid \mathrm{CuPcTs}$; and using visible light $(\lambda>420 \mathrm{~nm})$ and c) $\mathrm{CuPcTs}-\mathrm{Zn}_{3} \mathrm{Ga}_{\mid} \mathrm{CO}_{3}$ and d) $\mathrm{Zn}_{3} \mathrm{Ga} \mid \mathrm{CuPcTs}$. $\mathrm{CO}_{2}\left(\bullet\right.$; diamond), $\mathrm{H}_{2} \mathrm{O}\left(\boldsymbol{\Delta}\right.$; triangle), $\mathrm{CH}_{3} \mathrm{OH}$ (๘; square), and $\mathrm{CO}(\bullet ;$ circle $)$

selectivity of $54 \mathrm{~mol} \%$ (Tab. 2A entry e). The addition of $\mathrm{Au}$ to $\mathrm{Zn}_{3} \mathrm{Ga} \mid \mathrm{CO}_{3}$ promoted the total formation rates by a factor of 1.8 , but the methanol selectivity became only $13 \mathrm{~mol} \%$ (Tab. 2A entry f).

Next, photocatalytic reduction tests of $\mathrm{CO}_{2}$ by $\mathrm{H}_{2}$ were conducted irradiated by visible light $(\lambda>420 \mathrm{~nm})$. Although the $\mathrm{Zn}_{3} \mathrm{Ga} \mid \mathrm{CO}_{3} \mathrm{LDH}$ showed poor photoactivity irradiated by visible light (Tab. $2 \mathrm{~B}$ entry a), the total formation rate using CuPcTs- $\mathrm{Zn}_{3} \mathrm{Ga} \mid \mathrm{CO}_{3}$ irradiated by visible light was $73 \%$ of that irradiated by UV-visible light (Tab. 2B entry b). The methanol selectivity was maintained at $48-51 \mathrm{~mol} \%$ (Fig. 7 c-line). Again, under the condition of visible light irradiation, the formation of $\mathrm{CO}$ and methanol continued for more than $5 \mathrm{~h}$, demonstrating the stability of dispersed CuPcTs ${ }^{4-}$ over the $\mathrm{LDH}$ under $\mathrm{CO}_{2}+\mathrm{H}_{2}$.

The total formation rate using $\mathrm{Ag}-\mathrm{Zn}_{3} \mathrm{Ga} \mid \mathrm{CO}_{3}$ irradiated by visible light was $56 \%$ of that irradiated by UV-visible light (Tab. 2A entry c, Tab. 2B entry d). The selectivity to methanol decreased from $54 \mathrm{~mol} \%$ (irradiated by UVvisible light) to $29 \mathrm{~mol} \%$ (irradiated by visible light). Thus, $\mathrm{Ag}$ was less effective than $\mathrm{CuPcTs}^{4-}$ as a promoter under the condition of visible light irradiation. In comparison with the addition of $\mathrm{CuPcTs}^{4-}$ and $\mathrm{Ag}, \mathrm{Au}-\mathrm{Zn}_{3} \mathrm{Ga}_{\mid} \mathrm{CO}_{3}$ did not exhibit photocatalytic activity above the detection limit of GC irradiated under visible light (Tab. 2B, entry e).

The promotion effect of $\mathrm{CuPcTs}^{4-}$ to $\mathrm{Zn}_{3} \mathrm{Ga} \mid \mathrm{CO}_{3}$ was further investigated by plotting the in-profile (action) spectrum

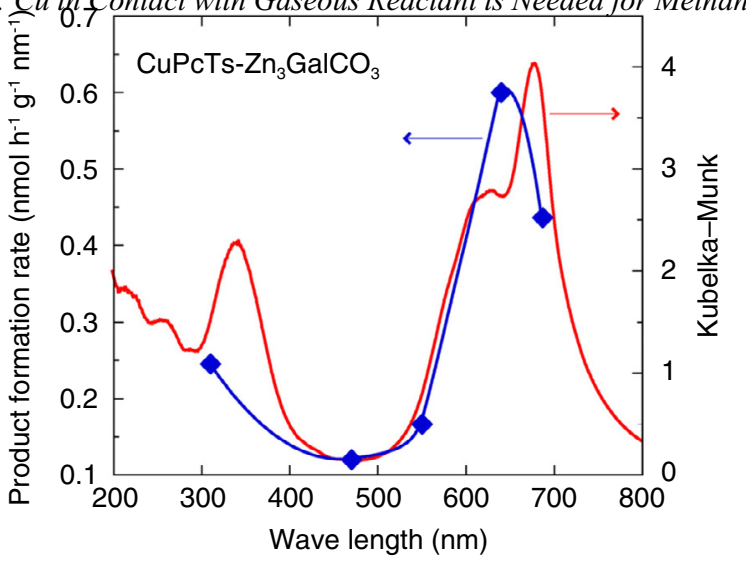

Figure 8

In-profile spectrum for CuPcTs- $\mathrm{Zn}_{3} \mathrm{Ga} \mid \mathrm{CO}_{3}$.

of total formation rates (methanol and $\mathrm{CO}$ ) based on the photocatalytic tests irradiated by the light of wavelengths progressively greater than $420,520,580,620,660$ and $715 \mathrm{~nm}$ using sharp cut filters (Fig. 8). The in-profile spectrum and UV-visible absorption spectrum coincided well in the wavelength ranges 310 and $688 \mathrm{~nm}$, demonstrating that the visible light absorption by $\mathrm{CuPcTs}^{4-}$ dispersed over $\mathrm{Zn}_{3} \mathrm{Ga} \mid \mathrm{CO}_{3}$ (Fig. 2b-line) led to electron excitation and then the reduction of $\mathrm{CO}_{2}$.

\section{DISCUSSION}

$\mathrm{Zn}_{3} \mathrm{Ga} \mid \mathrm{CO}_{3}$ exhibited photocatalytic reduction of $\mathrm{CO}_{2}$ by $\mathrm{H}_{2}$ and UV-visible light at a total formation rate (methanol and CO) of $130 \mathrm{nmol} \mathrm{h}^{-1} \mathrm{~g}_{\text {cat }}{ }^{-1}$ (Tab. 2A, entry a). When the amount of photocatalyst varied between 25 and $100 \mathrm{mg}$, the formation rate (the unit: $\mathrm{mol} \mathrm{h}^{-1}$ ) was essentially proportional to the amount (Ahmed et al., 2011; Yoshida et al., 2012).

Copper ions were doped as a part of $\mathrm{M}^{\mathrm{II}}$ cations in the cationic layer $\left[\mathrm{M}^{\mathrm{II}}{ }_{1-x} \mathrm{M}^{\mathrm{III}}{ }_{x}(\mathrm{OH})_{2}\right]^{x+}$ of $\mathrm{LDH}$ and $/$ or $\mathrm{Cu}(\mathrm{OH})_{4}{ }^{2-}$ anions between the cationic layers. Both inlayer and interlayer $\mathrm{Cu}$ sites were effective for photocatalytic reduction of $\mathrm{CO}_{2}$ (Ahmed et al., 2011, 2012). As a result, the total formation rate using $\mathrm{Zn}_{1.5} \mathrm{Cu}_{1.5} \mathrm{Ga} \mid \mathrm{Cu}(\mathrm{OH})_{4}$ was $560 \mathrm{nmol} \mathrm{h}^{-1} \mathrm{~g}_{\text {cat }}{ }^{-1}$ (Tab. 2A, entry k). Copper sites were primarily active for photocatalytic reduction of $\mathrm{CO}_{2}$ by $\mathrm{H}_{2}$.

The drawback of $\mathrm{LDH}$ comprising $\mathrm{Cu}$ was the limitation of the wavelength for excitation light. The estimated $E_{\mathrm{g}}$ values for the LDH used in this study were 5.6-3.0 eV (Tab. 1), indicating that only UV light was effective for $\mathrm{CO}_{2}$ photoreduction using $\mathrm{LDH}$ comprising $\mathrm{Cu}$. To overcome this drawback, $\mathrm{CuPcTs}^{4-}, \mathrm{Ag}$ or $\mathrm{Au}$ was doped to $\mathrm{Zn}_{3} \mathrm{Ga}_{\mid} \mathrm{CO}_{3}$. 


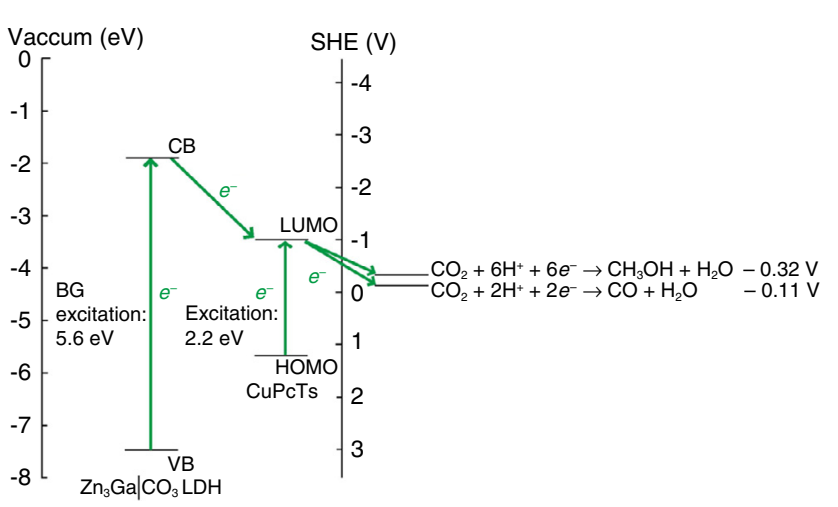

Figure 9

The energy diagram and proposed electron flows in $\mathrm{CuPcTs}-\mathrm{Zn}_{3} \mathrm{Ga} \mid \mathrm{CO}_{3}$ during photocatalytic reduction of $\mathrm{CO}_{2}$.

$\mathrm{CuPcTs}^{4-}, \mathrm{Ag}$ or $\mathrm{Au}$ in CuPcTs- $\mathrm{Zn}_{3} \mathrm{Ga}\left|\mathrm{CO}_{3}, \mathrm{Ag}-\mathrm{Zn}_{3} \mathrm{Ga}\right|$ $\mathrm{CO}_{3}$ and $\mathrm{Au}-\mathrm{Zn}_{3} \mathrm{Ga} \mid \mathrm{CO}_{3}$ photocatalysts were effective at boosting methanol and $\mathrm{CO}$ formation rates by a factor of 1.6-1.8 compared with $\mathrm{Zn}_{3} \mathrm{Ga} \mid \mathrm{CO}_{3}$, both irradiated by UV-visible light (Tab. 2A). The interlayer distance of the LDH changed negligibly for these photocatalysts (Fig. 1), demonstrating $\mathrm{CuPcTs}^{4-}, \mathrm{Ag}$ and $\mathrm{Au}$ were over the exterior surface of the LDH rather than the interlayer space (Kawamura et al., 2015). Under UV-visible light, band-gap excitation of the LDH occurred by UV light (Tab. 1), while HOMO-LUMO excitation (2.2 eV, Fig. 9; Giraudeau et al., 1980; Shang et al., 2011) of CuPcTs ${ }^{4-}$ and SPR of Ag and $\mathrm{Au}$ nanoparticles occurred by visible light.

The photocatalytic effects of UV and visible light were clarified by the photocatalytic tests irradiated by visible light only (Tab. $2 \mathrm{~B}$ ), and also the in-profile spectrum of $\mathrm{CO}_{2}$ photoreduction (Fig. 8). The formation rates of methanol and $\mathrm{CO}$ irradiated by visible light were $73-56 \%$ of those irradiated by UV-visible light using CuPcTs- $\mathrm{Zn}_{3} \mathrm{Ga}_{\mid} \mathrm{CO}_{3}$ and $\mathrm{Ag}-\mathrm{Zn}_{3} \mathrm{Ga} \mid \mathrm{CO}_{3}$, whereas $\mathrm{Au}-\mathrm{Zn}_{3} \mathrm{Ga} \mid \mathrm{CO}_{3}$ did not exhibit photocatalytic activity above the detection limit of GC under the irradiation of visible light. Thus, $\mathrm{CuPcTs}^{4-}$ was the best promoter for the LDH irradiated by visible light. The stability of $\mathrm{CuPcTs}^{4-}$ during photocatalytic tests was demonstrated (Fig. 2, 7a-c-line). Because the $E_{\mathrm{g}}$ value for $\mathrm{Zn}_{3} \mathrm{Ga}$ $\mathrm{CO}_{3}$ was $5.6 \mathrm{eV}$ (Tab. 1), the $\mathrm{LDH}$ did not participate in the catalysis under visible light but just dispersed CuPcTs ${ }^{4-}$ molecules on the external surface.

The energy diagram and proposed electron flow during $\mathrm{CO}_{2}$ photoreduction using CuPcTs- $\mathrm{Zn}_{3} \mathrm{Ga}_{\mid} \mathrm{CO}_{3}$ are depicted in Figure 9. As the HOMO-LUMO gap positions between Valence Bands (VB) and Conduction Bands (CB) of $\mathrm{Zn}_{3} \mathrm{Ga} \mid \mathrm{CO}_{3}$, band-gap excited electrons at $\mathrm{CB}$ and resultant holes at VB transfer to LUMO and HOMO of CuPcTs ${ }^{4-}$, respectively, irradiated by UV light. In fact, photogenerated electrons diffused to the central $\mathrm{Cu}(\mathrm{II})$ site of $\mathrm{CuPcTs}^{4-}$ at the rates of 2.7-21 $\mu \mathrm{mol} \mathrm{h}{ }^{-1}$ for $\mathrm{Na}^{+}{ }_{4} \mathrm{CuPcTs}^{4-}$ and CuPcTs- $\mathrm{Zn}_{3} \mathrm{Ga} \mid \mathrm{CO}$ (Fig. 5). $\mathrm{Na}^{+}{ }_{4} \mathrm{CuPcTs}^{4-}$ was able to photocatalyze $\mathrm{CO}_{2}$ to $\mathrm{CO}$ by $\mathrm{H}_{2}$ (Tab. 2A, entry d). When $\mathrm{CuPcTs}-\mathrm{Zn}_{3} \mathrm{Ga} \mid \mathrm{CO}_{3}$ was irradiated by visible light only, the band-gap excitation (5.6 eV) of $\mathrm{Zn}_{3} \mathrm{Ga} \mid \mathrm{CO}_{3}$ did not take place and only HOMO-LUMO excitation $(2.2 \mathrm{eV})$ of $\mathrm{CuPcTs}^{4-}$ was possible. The decrease in the formation rates of methanol and $\mathrm{CO}$ under visible light to $73 \%$ of those under UV-visible light (Tab. 2) can be explained by the decrease in the electron and hole supply from $\mathrm{Zn}_{3} \mathrm{Ga} \mid \mathrm{CO}_{3}$ to $\mathrm{CuPcTs}^{4-}$.

The LUMO of $\mathrm{CuPcTs}^{4-}$ does not exactly populate $\mathrm{Cu}$ sites but $\mathrm{N}$ atoms neighboring $\mathrm{Cu}$ sites (Fig. 3). Thus, the electrons excited to the $\mathrm{CB}$ of the $\mathrm{LDH}$ would transfer to LUMO (and/or an unoccupied level near LUMO) of $\mathrm{CuPcTs}^{4-}$. The energy level diagram of the LDH and $\mathrm{CuPcTs}^{4-}$ supported this hypothesis (Fig. 9).

The HOMO dominantly distribute on $\mathrm{C}$ atoms of pyrrole rings, while the LUMO dominantly distribute on both $\mathrm{C}$ and $\mathrm{N}$ atoms of pyrrole rings for $\mathrm{CuPcTs}^{4-}$ (Rauf et al., 2012). The $\mathrm{N}$ atoms of pyrrole are bonded to central $\mathrm{Cu}^{2+}$ ions and thus able to transfer the photo-excited electrons to $\mathrm{Cu}^{2+}$ (Fig. 3). $\mathrm{CO}_{2}$ would be progressively reduced by the reduced $\mathrm{Cu}^{+}$in a similar way to that by inlayer and interlayer $\mathrm{Cu}$ sites (Morikawa et al., 2014a; Ahmed et al., 2011, 2012). On the other hand, $\mathrm{H}_{2}$ would donate an electron to the position around HOMO (Fig. 3) to form $\mathrm{H}^{+}$. The proton combines the electron and $\mathrm{CO}_{2}$ at the $\mathrm{Cu}$ site and finally transforms into $\mathrm{CO}$ and methanol.

The SPR effect of Ag nanoparticles was already discussed in reference (Kawamura et al., 2015). In contrast, SPR of Au was not effective for the photoreduction of $\mathrm{CO}_{2}$ due to the greater work function of $\mathrm{Au}(5.31-5.47 \mathrm{eV})$ as compared with that of $\mathrm{Ag}$ (4.52-4.74 eV). Irradiated by UV-visible light, the Au surface played the role of an electron trap from $\mathrm{Zn}_{3} \mathrm{Ga} \mid \mathrm{CO}_{3}$.

LDH compounds especially comprising $\mathrm{Cu}$ and $\mathrm{Ga}$ selectively photoproduced methanol from $\mathrm{CO}_{2}+\mathrm{H}_{2}(68-88 \mathrm{~mol} \%$, Tab. 1). A reaction mechanism via hydrogen carbonate bound to $\mathrm{Cu}$ was proposed based on FTIR and XAFS (Ahmed et al., 2011; Morikawa et al., 2014a). These LDH photocatalysts would be combined with a photooxidation catalyst, e.g. $\mathrm{WO}_{3}$, to produce methanol from $\mathrm{CO}_{2}+\mathrm{H}_{2} \mathrm{O}$ (Morikawa et al., 2014b).

\section{CONCLUSIONS}

$\mathrm{LDH}$ comprising $\mathrm{Zn}$ and $\mathrm{Al}$ or $\mathrm{Ga}$ photoreduced $\mathrm{CO}_{2}$ to $\mathrm{CO}$ and methanol by $\mathrm{H}_{2}$ and the irradiation of $\mathrm{UV}$-visible light. 
S. Kawamura et al. / Photocatalytic Conversion of Carbon Dioxide Using Zn-Cu-Ga Layered Double Hydroxides Assembled 851 with Cu Phthalocyanine: Cu in Contact with Gaseous Reactant is Needed for Methanol GenerationPhotocatalytic Conversion of Carbon Dioxide Using

ZWhen-Ga Lavered Double Hydroxides Assembled with Cu Phthalocyanine: Cu in Gontact with Gaseous Reactant is Neesdedfor Methanol and/or as interlayer anions, the $\mathrm{CO}_{2}$ photoreduction rates increased to as high as $560 \mathrm{nmol} \mathrm{h}^{-1} \mathrm{~g}_{\text {cat }}{ }^{-1}\left(\mathrm{Zn}_{1.5} \mathrm{Cu}_{1.5} \mathrm{Ga}\right.$ | $\mathrm{Cu}(\mathrm{OH})_{4}$ photocatalyst). Due to the wide band-gap nature of these LDH, UV light was effective for $\mathrm{CO}_{2}$ photoreduction. The doping of $\mathrm{CuPcTs}^{4-}$ and $\mathrm{Ag}$ to the $\mathrm{Zn}_{3} \mathrm{Ga} \mid \mathrm{CO}_{3}$ $\mathrm{LDH}$ boosted $\mathrm{CO}_{2}$ photoreduction by a factor of 1.6-1.8 by $\mathrm{H}_{2}$ and the irradiation of UV-visible light. CuPcTs ${ }^{4-}$ was especially effective doped to the $\mathrm{LDH}$ for $\mathrm{CO}_{2}$ photoreduction irradiated by visible light only. The LUMO of $\mathrm{CuPcTs}^{4-}$ was distributed on $\mathrm{N}$ atoms of pyrrole rings bound to central $\mathrm{Cu}^{2+}$ ions. The photo-excited electrons diffused to central $\mathrm{Cu}^{2+}$ would progressively reduce $\mathrm{CO}_{2}$ finally to $\mathrm{CO}$ and methanol in a similar way to the inlayer and interlayer $\mathrm{Cu}$ sites in the $\mathrm{LDH}$ in this study.

\section{ACKNOWLEDGMENTS}

The authors are grateful for the financial support from the Grant-in-Aid for Scientific Research C (26410204, 22550117) from the Japan Society for the Promotion of Science, Asahi Grass Foundation, Promotion Section of Technology Innovation, Daikin Industries, and from the Romanian National Authority for Scientific Research (PN-IIIDEI-PCE-75/2013). X-ray absorption experiments were conducted under the approval of the Photon Factory Proposal Review Committee (2011G033, 2009G552, 2007G576) and Grant of the Priority Program for Disaster-Affected Quantum Beam Facilities (2011A1977, SPring-8 \& KEK).

\section{REFERENCES}

Abellán G., Busolo F., Coronado E., Martí-Gastaldo C., Ribera A. (2012) Hybrid Magnetic Multilayers by Intercalation of $\mathrm{Cu}(\mathrm{II})$ Phthalocyanine in LDH Hosts, J. Phys. Chem. C 116, 29, 15756-15764.

Ahmed N., Morikawa M., Izumi Y. (2013) Photocatalytic Conversion of Carbon Dioxide into Fuels Using Layered Double Hydroxides Coupled with Hydrogen or Water, in New and Future Developments in Catalysis: Activation of Carbon Dioxide, Suib S.L. (ed.), Elsevier, pp. 589-602.

Ahmed N., Morikawa M., Izumi Y. (2012) Photocatalytic conversion of carbon dioxide into methanol using optimized layered double hydroxide catalysts, Catal. Today 185, 263-269.

Ahmed N., Shibata Y., Taniguchi T., Izumi Y. (2011) Photocatalytic conversion of carbon dioxide into methanol using zinc-copper-M (III) ( $\mathrm{M}=$ aluminum, gallium) layered double hydroxides, J. Catal. 279, 123-135.

Bearden J.A. (1967) X-Ray Wavelengths, Rev. Mod. Phys. 39, 1, 78-124.

Carrera F., Marcos E.S., Merkling P.J., Chaboy J., Muñoz-Páez A. (2004) Nature of Metal Binding Sites in $\mathrm{Cu}$ (II) Complexes with Histidine and Related N-Coordinating Ligands, As Studied by EXAFS, Inorg. Chem. 43, 21, 6674-6683.

plasmonic gold/layered double hydroxides and derived mixed oxides as novel photocatalysts for hydrogen generation under solar irradiation, J. Mater. Chem. A 132, 9092-9098.

Cavani F., Trifirò F., Vaccari A. (1991) Hydrotalcite-type anionic clays: preparation, properties and applications, Catal. Today 11, 173-301.

Costentin C., Robert M., Savéant J.M. (2013) Catalysis of the electrochemical reduction of carbon dioxide, Chem. Soc. Rev. 42, 6, 2423-2436.

Corma A., García H. (2013) Photocatalytic reduction of $\mathrm{CO}_{2}$ for fuel production: Possibilities and challenges, J. Catal. 308, 168-175.

Fan G., Li F., Evans D.G., Duan X. (2014) Catalytic applications of layered double hydroxides: recent advances and perspective, Chem. Soc. Rev. 43, 20, 7040-7066.

Genevese C., Ampelli C., Parathoner S., Centi G. (2013) Electrocatalytic conversion of $\mathrm{CO}_{2}$ to liquid fuels using nanocarbon-based electrodes, J. Energy Chem. 22, 2, 202-213.

Giraudeau A., Fan F.F., Bard A.J. (1980) Semiconductor Electrodes. 30. Spectral Sensitization of the Smiconductors $n-\mathrm{TiO}_{2}$ and $n-\mathrm{WO}_{3}$ with Metal Phthalocyanines, J. Am. Chem. Soc. 102, $16,5137-5142$.

Habisreutinger S.N., Schmidt-Mende L., Stolarczyk J.K. (2013) Photocatalytic Reduciton of $\mathrm{CO}_{2}$ on $\mathrm{TiO}_{2}$ and Other Semiconductors, Angew. Chem. Int. Ed. 52, 29, 7372-7408.

Indrakanti V.P., Kubicki J.D., Schobert H.H. (2009) Photoinduced activation of $\mathrm{CO}_{2}$ on Ti-based heterogeneous catalysts: Current state, chemical physics-based insights and outlook, Energy Environ. Sci. 2, 7, 745-758.

Izumi Y. (2013) Recent advances in the photocatalytic conversion of carbon dioxide to fuels with water and/or hydrogen using solar energy and beyond, Coord. Chem. Rev. 257, 171-186.

Izumi Y., Itoi T., Peng S., Oka K., Shibata Y. (2009) Site Structure and Photocatalytic Role of Sulfur or Nitrogen-Doped Titanium Oxide with Uniform Mesopores under Visible Light, J. Phys. Chem. C 113, 16, 6706-6718.

Izumi Y., Konishi K., Obaid D., Miyajima T., Yoshitake H. (2007) X-ray Absorption Fine Structure Combined with X-ray Fluorescence Spectroscopy. Monitoring of Vanadium Sites in Mesoporous Titania, Excited under Visible Light by Selective Detection of Vanadium K $\beta_{5,2}$ Fluorescence, Anal. Chem. 79, 18, 6933-6940.

Izumi Y., Kiyotaki F., Yagi N., Vlaicu A.M., Nisawa A., Fukushima S., Yoshitake H., Iwasawa Y. (2005) X-ray Absorption Fine Structure Combined with X-ray Fluorescence Spectrometry. Part 15. Monitoring of Vanadium Site Transformations on Titania and in Mesoporous Titania by Selective Detection of the Vanadium $\mathrm{K}_{1}$ Fluorescence, J. Phys. Chem. 109, 31, 14884-14891.

Kawamura S., Cornelia P.M., Yoshida Y., Izumi Y., Carja G. (2015) Tailoring assemblies of plasmonic silver/gold and zinc-gallium layered double hydroxides for photocatalytic conversion of carbon dioxide using UV-visible light, DOI: 10.1016/j.apcata.2014.12.042.

Kubacka A., Fernández-García M., Colón G. (2012) Advanced Nanoarchitectures for Solar Photocatalytic Applications, Chem. Rev. 112, 3, 1555-1614.

Lewis N.S., Nocera D.G. (2006) Powering the planet: Chemical challenges in solar energy utilization, Proc. Natl. Acad. Sci. U. S. A. 103, 43, 15729-15735.

Li C., Wei M., Evans D.G., Duan X. (2014) Layered Double Hydroxide-based Nanomaterials as Highly Efficient Catalysts and Adsorbents, Small 10, 22, 4469-4486. 
Lv H., Geletii Y.V., Zhao C., Vickers J.W., Zhu G., Luo Z., Song J., Lian T., Musaev D.G., Hill C.L. (2012) Polyoxometalate water oxidation catalysts and the production of green fuel, Chem. Soc. Rev. 41, 22, 7572-7589.

Marom N., Hod O., Scuseria G.E., Kronik L. (2008) Electronic structure of copper phthalocyanine: A comparative density functional theory study, J. Chem. Phys. 128, 16, 164107.

Morikawa M., Ahmed N., Yoshida Y., Izumi Y. (2014a) Photoconversion of carbon dioxide in zinc-copper-gallium layered double hydroxides: The kinetics to hydrogen carbonate and further to CO/methanol, Appl. Catal. B 144, 561-569.

Morikawa M., Ogura Y., Ahmed N., Kawamura S., Mikami G., Okamoto S., Izumi Y. (2014b) Photocatalytic conversion of carbon dioxide into methanol in reverse fuel cells with tungsten oxide and layered double hydroxide photocatalysts for solar fuel generation, Catal. Sci. Technol. 4, 6, 1644-1651.

Parida K.M., Baliarsingh N., Patra B.S., Das J. (2007) Copperphthalocyanine immobilized $\mathrm{Zn} / \mathrm{Al} \mathrm{LDH}$ as photocatalyst under solar radiation for decolorization of methylene blue, J. Mol. Catal. A. 267, 202-208.

Rauf M.A., Hisaindee S., Graham J.P., Nawaz M. (2012) Solvent effects on the absorption and fluorescence spectra of $\mathrm{Cu}(\mathrm{II})-$ phthalocyanine and DFT calculations, J. Mol. Liquids $\mathbf{1 6 8}$, 102-109.

Roy S.C., Varghese O.K., Paulose M., Grimes C.A. (2010) Toward Solar Fuels: Photocatalytic Conversion of Carbon Dioxide to Hydrocarbons, ACS Nano 4, 3, 1259-1278.
Shang J., Zhao F., Zhu T., Li J. (2011) Photocatalytic degradation of rhodamine $\mathrm{B}$ by dye-sensitized $\mathrm{TiO}_{2}$ under visible-light irradiation, Sci. China Chem. 54, 1, 167-172.

Sideris P.J., Nielsen U.G., Gan Z., Grey C.P. (2008) Mg/Al Ordering in Layered Double Hydroxides Revealed by Multinuclear NMR Spectroscopy, Science 321, 5885, 113-117.

Vaarkamp M., Linders H., Koningsberger D. (2006) XDAP version 2.2.7, XAFS Services International, Woudenberg, The Netherlands.

Wooten F. (1972) Optical Properties of Solids, Academic Press, New York, USA, p. 142.

Yoshida Y., Mitani Y., Itoi T., Izumi Y. (2012) Preferential oxidation of carbon monoxide in hydrogen using zinc oxide photocatalysts promoted and tuned by adsorbed copper ions, J. Catal. 287, 190-202.

Zümreoglu-Karan B., Ay A.N. (2012) Layered double hydroxidemultifunctional nanomaterials, Chem. Papers 66, 1, 1-10.

Manuscript submitted in October 2014

Manuscript accepted in May 2015

Published online in September 2015

Cite this article as: S. Kawamura, N. Ahmed, G. Carja and Y. Izumi (2015). Photocatalytic Conversion of Carbon Dioxide Using $\mathrm{Zn}-\mathrm{Cu}-\mathrm{Ga}$ Layered Double Hydroxides Assembled with $\mathrm{Cu}$ Phthalocyanine: $\mathrm{Cu}$ in Contact with Gaseous Reactant is Needed for Methanol Generation, Oil Gas Sci. Technol 70, 5, 841-852. 